Georgetown University Law Center

Scholarship @ GEORGETOWN LAW

2014

\title{
Potential Competitive Effects of Vertical Mergers: A How-To Guide for Practitioners
}

Steven C. Salop

Georgetown University Law Center, salop@law.georgetown.edu

Daniel P. Culley

Cleary Gottlieb Steen \& Hamilton, LLP, dculley@cgsh.com

This paper can be downloaded free of charge from:

https://scholarship.law.georgetown.edu/facpub/1392

http://ssrn.com/abstract=2522179

This open-access article is brought to you by the Georgetown Law Library. Posted with permission of the author. Follow this and additional works at: https://scholarship.law.georgetown.edu/facpub

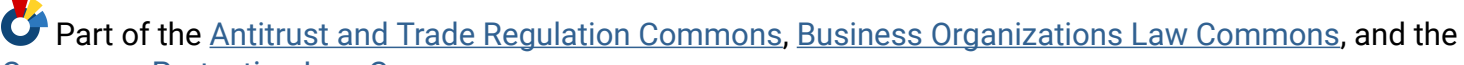
Consumer Protection Law Commons 


\title{
Potential Competitive Effects of Vertical Mergers: A How-To Guide for Practitioners
}

\author{
Steven C. Salop and Daniel P Culley ${ }^{1}$
}

\section{Table of Contents}

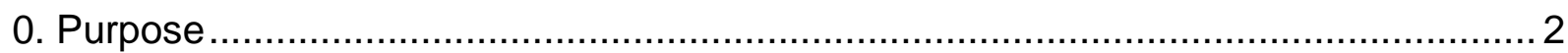

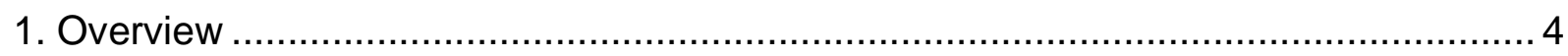

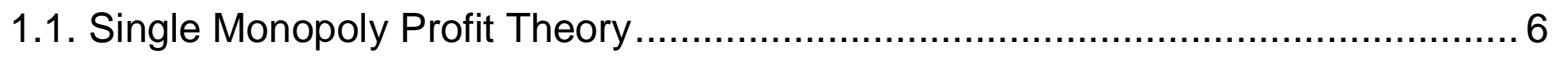

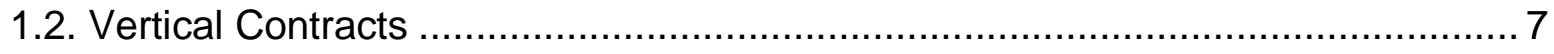

1.3. Harm to the Downstream Rivals of Merged Firm ........................................... 7

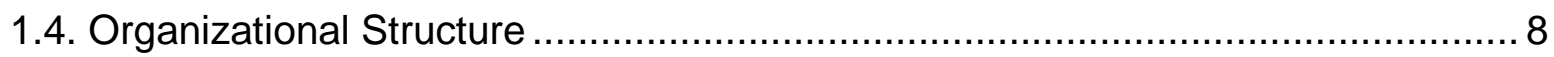

2. Market Definition, Market Shares, and Concentration ........................................ 8

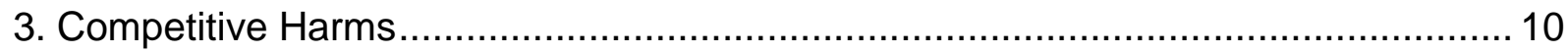

4. Elimination or Reduction in Potential Competition .............................................. 11

4.1. Merging Firms as Potential Entrants ...................................................... 11

4.2. Merging Firms as Potential Entry Facilitators ........................................... 12

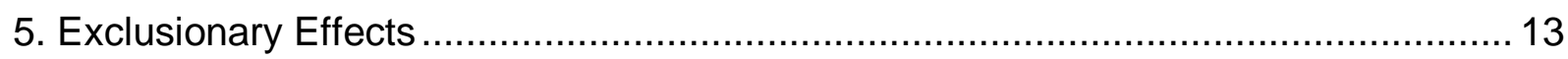

1 The authors are Professor of Economics and Law, Georgetown University Law Center; Senior Consultant, Charles River Associates (Salop); Associate, Cleary Gottlieb Steen \& Hamilton, LLP (Culley). We would like to thank Mark Angland, Jonathan Baker, Matthew Cantor, Dennis Carlton, Mark Israel, James Kearl, James Langenfeld, Doug Melamed, Serge Moresi, Michael Salinger, Carl Shapiro, Joe Sims, Toby Singer, Richard Steuer, and John Woodbury for helpful comments on a previous draft. This article flows from Professor Salop's ongoing collaboration with Serge Moresi on these issues. The authors have consulted or represented parties involved in some of the cases used as examples in this article as well as others. All opinions and errors remain our own and do not necessary represent the views of our colleagues or clients. We would appreciate comments and suggestions from readers in order to improve this How-To Guide. 
5.1. Input Foreclosure 14

5.1.1. Gauging Input Foreclosure Effects.................................................... 17

5.1.2. Input Foreclosure Threats ................................................................ 19

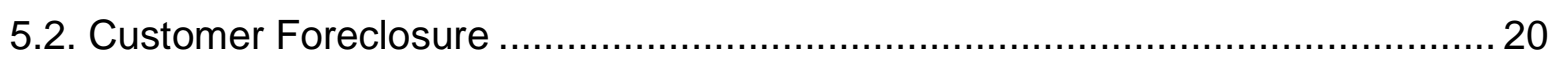

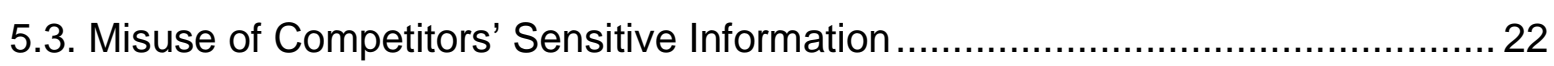

6. Unilateral Competitive Incentives to Raise Downstream Prices ............................. 23

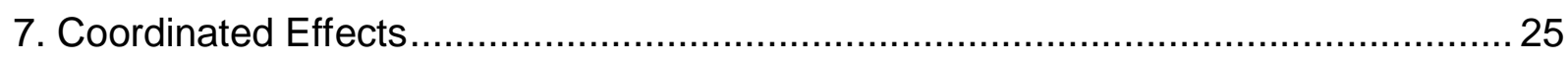

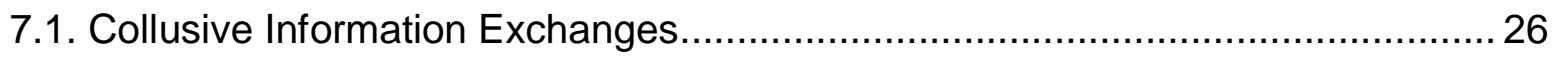

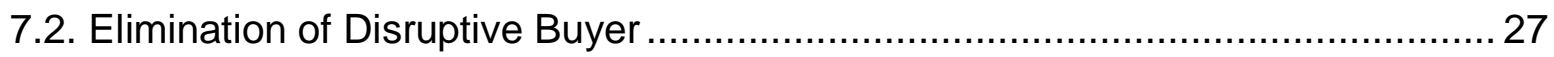

7.3. Weakening Maverick or Disruptive Competitive Behavior Downstream .............27

7.4. Using Lower Costs to Facilitate Consensus or Increase the Ability Punish

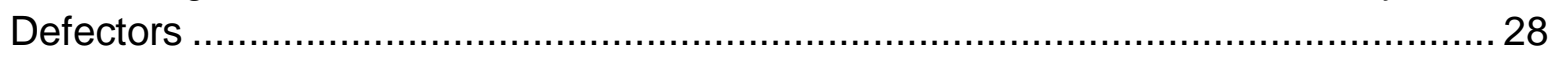

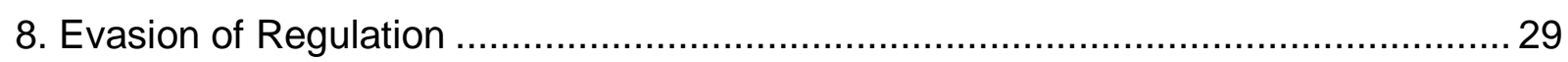

9. Harmful Price Discrimination ........................................................................ 30

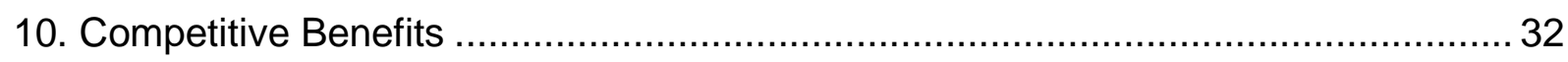

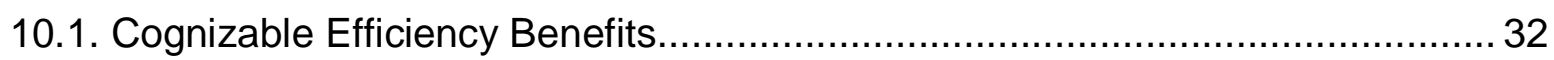

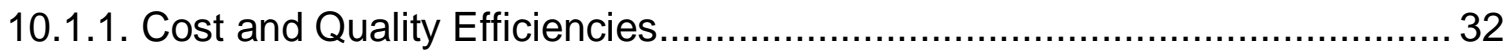

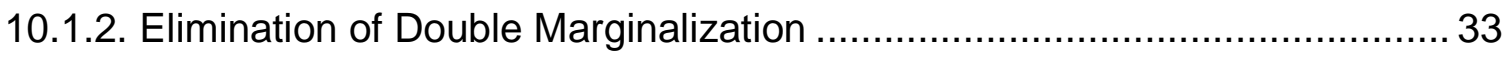

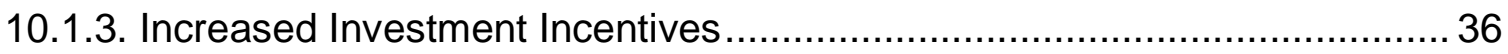

10.2. Reduced Likelihood of Coordination ........................................................ 37

11. Complementary Product Mergers................................................................ 37

12. Partial Ownership Acquisitions ......................................................................... 40

Appendix: Vertical Merger Challenges (1994-2013) ............................................ 42

\section{Purpose}

The purpose of this article is to provide practitioners with the tools for carrying out a competitive effects analysis of vertical and complementary product mergers. The U.S. Vertical Merger Guidelines have not been revised since they were initially released in 
$1984 .^{2}$ Those Guidelines are now out of date. They do not reflect current economic thinking about vertical mergers or current agency practice. ${ }^{3}$ Nor do they reflect the approach taken in the 2010 Horizontal Merger Guidelines. ${ }^{4}$ As a result, practitioners and firms lack the benefits of up-to-date guidance from the U.S. enforcement agencies. The same is true for foreign jurisdictions that might look to the U.S. for guidance. Instead, the most modern guidelines are those issued by the European Commission in $2008 .^{5}$

This article is intended to partially fill the gap. This article obviously cannot state the current enforcement intentions of the DOJ and the FTC. Instead, it summarizes the potential harms and benefits from vertical mergers and suggests the types of factual and economic issues that practitioners would need to analyze, and questions they would need to ask, in order to predict the likely competitive effects of vertical mergers during the merger review process.

The Antitrust Modernization Commission and the ABA's 2012 Presidential Transition Report both recommended that the Vertical Merger Guidelines be revised. ${ }^{6}$ However,

2 U.S. Dep't of Justice, Non-Horizontal Merger Guidelines (1984), available at www. justice.gov/atr/public/guidelines/2614.pdf.

${ }^{3}$ For example, see Michael H. Riordan \& Steven C. Salop, Evaluating Vertical Mergers: A Post-Chicago Approach, 63 ANTITRUST L.J. 513 (1995); David Sibley \& Michael J. Doane, Raising the Costs of Unintegrated Rivals: An Analysis of Barnes \& Noble's Proposed Acquisition of Ingram Book Company, in MEASURING MARKET POWER 211 (Daniel J. Slottje ed., 2002); Jeffrey Church, Vertical Mergers, in 2 ABA SECTION OF ANTITRUST LAW, ISSUES IN COMPETITION LAW AND POLICY 1455 (W. Dale Collins ed., 2008); Michael H. Riordan, Competitive Effects of Vertical Integration, in HANDBOOK OF ANTITRUST ECONOMICS 145 (Paolo Buccirossi ed., 2008). See also the sources cited in these articles.

${ }^{4}$ United States Department of Justice and Federal Trade Commission, Horizontal Merger Guidelines (August 19, 2010) [hereinafter, 2010 Horizontal Merger Guidelines], available at www.ftc.gov/os/2010/08/100819hmg.pdf.

${ }^{5}$ European Comm'n, Guidelines on the Assessment of Non-Horizontal Mergers Under the Council Regulation on the Control of Concentrations Between Undertakings, 2008 O.J. (C 265) 6.

${ }^{6}$ American Bar Association Section of Antitrust Law, PRESIDENTIAL TRANSITION REPORT: THE STATE OF ANTITRUST LAW 2012 (February 2013) (hereinafter ABA Report) at 7, available at www.americanbar.org/content/dam/aba/administrative/antitrust_law/at_comments_presidential_ 201302.authcheckdam.pdf; Antitrust Modernization Commission, REPORT AND RECOMMENDATIONS 68 (2007) (hereinafter AMC Report). For a more skeptical view of the need for revising the Guidelines, see Frederick R. Warren-Boulton, The Contribution of the Merger Guidelines to the Analysis of Non-Horizontal Mergers, $20^{\text {th }}$ Anniversary of the 1982 
there have been no efforts in this direction. There appear to be two primary arguments against revising the Guidelines. One is that there is so little enforcement, and the ways in which vertical mergers can harm competition are so myriad, that it would not be costeffective for the agencies to devote all the effort required for revising the Guidelines. The other argument is that revised Guidelines likely would lead to more enforcement. ${ }^{7}$

Vertical merger enforcement is less common than horizontal enforcement. It also varies more from one administration to another. According to our count, there have been 46 vertical enforcement actions in the 1994-2013 period of 20 years. The DOJ and FTC brought about 31 enforcement challenges during the two Clinton administration terms. During the two G.W. Bush administration terms, the two agencies brought only 7 enforcement actions. ${ }^{8}$ And, through 2013 of the Obama administration, the two agencies have brought 8 enforcement actions. ${ }^{9} \mathrm{~A}$ listing of these cases, the allegations and outcomes are summarized in the Appendix to this article.

A second purpose of this article is to reduce the workload involved in revising the Guidelines. By summarizing the categories and analysis of harms and benefits, listing the type of relevant evidence, and summarizing the enforcement actions over the past 20 years, the agencies will able to save time and effort. In addition, this article also identifies several legal and policy issues that are raised by that analysis and might be examined by the agencies and the parties during the review process. These issues also would be relevant if and when the agencies revise the Guidelines.

\section{Overview}

Vertical mergers combine firms at different levels of production or distribution, whereas horizontal mergers combine firms at the same level. In the simplest case, a vertical merger joins together a firm that produces an input (and competes in an input market) with a firm that uses that input to produce output (and competes in an output market). Acquisition of intellectual property by a company that uses that intellectual property, or who competes with other firms that do, also is a type of vertical merger. A transaction

Merger Guidelines: The Contribution of the Merger Guidelines to the Evolution of Antitrust Doctrine, May 21, 2002, available at www.usdoj.gov/atr/hmerger.htm\#papers.

7 ABA Report at 8-9. Deborah L. Feinstein, Are the Vertical Merger Guidelines Ripe for Revision, 24 ANTITRUST 5, 6-7 (Summer 2010).

8 In News Corp.'s acquisition of a stake in the parent company of DirecTV, the DOJ did not take enforcement action in reliance of the FCC's remedy. See infra n. 36 and accompanying text.

We therefore do not include it in our count.

9 These counts update the earlier enforcement statistics in Steven C. Salop, What Consensus? Why Ideology and Politics Still Matter to Antitrust, 79 ANTITRUST L.J. 601, 624-26 (2014). 
may involve both horizontal and vertical elements, as when a vertically integrated firm acquires a competitor in one of the markets. In addition, a transaction that is primarily horizontal may involve some vertical elements, if competitors rely to some extent on inputs supplied by one of the merging firms or benefit from product compatibility. A merger of firms producing complementary products also is analytically similar to a vertical merger.

Most vertical mergers do not raise competitive concerns and likely are procompetitive. Firms at different levels of production may need to cooperate in order to design, produce and distribute their goods and services. Vertical mergers may increase the efficiency of this process by improving communication and harmonizing the incentives of the merging firms. These benefits may include cost reduction and improved product design that can lead to lower prices, higher-quality products, and increased investment and innovation. By reducing the cost of inputs used by the downstream division of the merged firm, a vertical merger also can create an incentive for price reductions. In markets vulnerable to coordination, a vertical merger might lead to creation or enhancement of a maverick or disruptive firm, or it might disrupt oligopoly coordination in other ways.

Vertical mergers also can raise various competitive concerns. As noted in the DOJ's Policy Guide to Merger Remedies, "vertical mergers can create changed incentives and enhance the ability of the merged firm to impair the competitive process." ${ }^{10}$ As a result, vertical mergers can lead to the achievement, enhancement, or maintenance of market power that harms consumers and competition. Vertical mergers also can facilitate the harmful exercise of pre-existing market power. All of these effects can lead to higher prices, reduced product quality, reduced variety and lessened investment and innovation. The goal of vertical merger law and policy is to block or remedy mergers that likely may lead to these harmful effects. These competitive benefits and harms similarly can occur from mergers of firms producing complementary products.

While the details of the analysis vary for different categories of concerns, the focus of the competitive effects analysis is the same-to predict whether or not the merger may lead to higher prices or other harmful effects in the markets affected by the merger. A vertical merger can affect competition in either or both of the upstream (input) market and the downstream (output) market. It is also possible that additional markets will be adversely affected by the merger. ${ }^{11}$ In analyzing these markets, the identification of

\footnotetext{
${ }^{10}$ U.S. Dep't of Justice, Antitrust Division Policy Guide to Merger Remedies 5 (2011), www.justice.gov/atr/public/guidelines/272350.pdf. We do not discuss remedies in this article.

${ }^{11}$ Exclusionary or coordinated effects could lead to effects in output markets in which the downstream firms compete but do not use the input. For example, if there are strong
} 
which is the upstream market and which is the downstream markets may vary. For example, distributors are the customers of manufacturers, but distribution services also are a critical input required by manufacturers. Thus, it is often useful to treat distributors as input providers rather than as customers.

As with horizontal mergers, a full analysis of the competitive effects of a vertical merger would examine the potential competitive benefits and harms in order to predict the likely net competitive effect on consumers and competition. The fact that multiple markets normally are affected makes the analysis more complex. It also raises a legal and policy issue when competition is harmed in one market but benefited in another market. This is one of the issues that will need to be resolved in revised Guidelines.

\subsection{Single Monopoly Profit Theory}

It sometimes is suggested that vertical mergers in unregulated markets are unlikely to raise competitive concerns because there is only a "single monopoly profit" and so monopoly power cannot profitably be extended to other markets. ${ }^{12}$ This economic theory sometimes has been used to claim that vertical mergers are seldom (if ever) anticompetitive. However, the conditions for this theory rarely hold, and the broad claim that there is a single monopoly profit can obscure how a particular merger may raise real competitive concerns.

Vertical mergers seldom involve firms that have monopolies protected by prohibitive entry barriers. If there is no monopoly, then there is no single monopoly profit. As a practical matter, a merger may lead to foreclosure that leads to market or monopoly power in one or both of the markets. A merger also may permit firms to achieve or enhance express or tacit pricing coordination or parallel accommodating conduct. Even if the upstream firm has a dominant market share, it may face potential competition from downstream firms or other entrants, including its downstream merger partner, and the merger may eliminate the role of the downstream merging partner in facilitating that entry. Even where there is dominance and no threat of potential competition, a merger may facilitate harmful price discrimination or evasion of price regulation.

The intuition flowing from the single monopoly profit theory sometimes is used to argue that dominant firms may be able to extract profits from other levels of distribution pre-

economies of scope, then input foreclosure in the downstream market could lead to higher prices in the related market. Similarly, there could be effects in input markets in which the upstream firms compete but the downstream division of the merged firm does not compete.

12 The classic formulation of the single monopoly profit theory set out in the context of tying is Ward S. Bowman, Tying Arrangements and the Leverage Problem, 67 YALE L. J. 19 (1957) 
merger through conduct such as non-linear pricing. This same argument would apply to the firm's pre-merger ability to eliminate double marginalization. Where this pre-merger conduct occurs, these effects should not be double-counted in analyzing the merger. Thus, the theory might suggest that unilateral effects concerns and elimination of double marginalization benefits may be less significant than otherwise thought. But the magnitude of those effects would vary, based on the conditions in an individual market, and so would need to be evaluated on a case-by-case basis. In addition, the other potential harms still might occur. For these reasons, the single monopoly profit theory is not an appropriate rationale for limiting vertical merger enforcement generally.

\subsection{Vertical Contracts}

Exclusionary harms and certain efficiency benefits also might be achieved with vertical contracts and agreements without the need for a vertical merger. For this reason, it might be argued that certain efficiency claims are not merger-specific. But there may be impediments, such as transaction costs or incomplete contracting, to achieving efficiencies through contract. It similarly might be argued that the absence of premerger exclusionary contracts implies that the merging firms lack the incentive to engage in conduct that would lead to harmful exclusionary effects. But anticompetitive vertical contracts may face the same types of impediments as procompetitive ones, and may also be deterred by potential Section 1 enforcement. ${ }^{13}$ Neither of these arguments thus justify a more or less intrusive vertical merger policy generally. Rather, they are factors that should be considered in analyzing individual mergers.

\subsection{Harm to the Downstream Rivals of Merged Firm}

One policy issue that would need to be resolved in revised Vertical Merger Guidelines is whether enforcement should be undertaken only when there is reliable evidence of a sufficient likelihood of harm to the customers in the downstream market, or whether there are ever circumstances under which harm to the customers of the upstream firms

\footnotetext{
${ }^{13}$ For example, while the merging firms may have had the incentive to achieve exclusionary effects through exclusionary contracts in the pre-merger world, such contracts may have been subject to a variety of impediments, such as bargaining, coordination, informational, and free rider problems. A vertical merger may be a more effective way to avoid these "transaction costs" and achieve anticompetitive profits. Second, anticompetititve vertical exclusionary contracts may have been deterred by Section 1 of the Sherman Act. Legal prohibitions are a classic transaction cost. Thus, the theoretical possibility that the parties or non-merging firms did not implement exclusionary conduct via contract firms does not indicate that the vertical merger enforcement is unnecessary, any more than the theoretical possibility that parties could achieve efficiencies through contract would indicate that analyzing efficiencies is unnecessary.
} 
(i.e., the downstream competitors other than the downstream merging party) should be sufficient to warrant enforcement action. The policy might not be the same for every type of harm. ${ }^{14}$ For example, harm to the downstream competitors might be viewed as sufficient if the concern is that the merger would create hub-and-spoke collusion in the input market. However, if the concern is that the merger would cause exclusionary effects, then it might be necessary to show harm to consumers who purchase the downstream product.

\subsection{Organizational Structure}

The remainder of this article describes the analysis of competitive harms and competitive benefits. After discussing the role and measurement of market shares and concentration in Section 2, potential competitive harms are discussed in Sections 3-9. Potential competitive benefits are discussed in Section 10. Because there are a myriad ways in which the competitive harms can occur, and some have been less well articulated, each type of harm is discussed in a separate section. However, this imbalance in the number of sections is not intended to suggest that vertical mergers are presumptively likely to be anticompetitive. Nor is the fact the harms are discussed before benefits. Complementary product mergers are discussed in Section 11 and partial ownership interests are discussed in Section 12.

\section{Market Definition, Market Shares, and Concentration}

The same basic principles of market definition and of calculating market shares and concentration apply to vertical mergers as they do for horizontal mergers.

Despite the well-known shortcomings of concentration statistics, the Horizontal Merger Guidelines have safe harbors and anticompetitive presumptions based on HHIs. In a vertical merger, there is no change in the HHI. However, the markets shares of the merging firms and the HHIs at the upstream and downstream levels in principle might be used to create safe harbors or anticompetitive presumptions. ${ }^{15}$ The 1984 Vertical

\footnotetext{
14 The 2010 Horizontal Merger Guidelines do not require a showing of harm to consumers in the case of buyer-side horizontal mergers, only harm to the upstream buyers. The Horizontal Merger Guidelines do not explain how to balance these harms against any efficiencies that would reduce the cost of the merging firms and be passed through to consumers. See 2010 Horizontal Merger Guidelines § 12.

15 Several other modified "vertical HHI" measures have been proposed in the economic literature, based on different economic models of the upstream market. See Joshua S. Gans, Concentration-Based Merger Tests and Vertical Market Structure, 50 J.L. \& ECON. 661 (2007). If the Vertical Merger Guidelines are revised, some might support considering those "vertical HHIs" for reference into the Guidelines.
} 
Merger Guidelines had a quasi-safe harbor for markets that were not highly concentrated. Whether to include safe harbors and anticompetitive presumptions, and what form they should take, is another policy issue that would be raised when the Guidelines are revised.

The agencies should be cautious about using market share and $\mathrm{HHI}$ measures as summary measures of competitive concerns in vertical mergers. For example, the upstream merging firm may currently have a large market share, but that share may not be reflective of market power if other competitors have the ability and incentive to rapidly expand and do not have capacity constraints. If that is the case, attempting input foreclosure of the downstream firms' rivals may be unprofitable. Similarly, the upstream merging firm may currently have a small market share, but its ability and incentive to rapidly expand may be disciplining the pricing of other upstream firms. If that is the case, the merger might lead to profitable input foreclosure by permitting the other upstream firms to raise their prices, disadvantaging the downstream firms' rivals.

Vertical mergers may also raise unilateral effects concerns, both directly and through foreclosure strategies, as discussed below. The $\mathrm{HHI}$ and market shares may not be the best proxies for evaluating these concerns. As noted in the 2010 Horizontal Merger Guidelines, the agencies "rely much more on the value of diverted sales than on the level of the $\mathrm{HHI}$ for diagnosing unilateral price effects in markets with differentiated products." 16

Market shares also may provide poor proxies for certain types of concerns about coordination. For example, a low market share is not inconsistent with the upstream merging firm being a maverick or disruptive firm, or with the downstream merging firm being a disruptive buyer. Similarly, market shares are not generally relevant to the ability and incentive to use one of the divisions to exchange competitively sensitive information with rivals in the other market, although the HHls and market shares may provide some indication about the likely gains and harmful effects from doing so.

If the agencies were to create safe harbors or presumptions based on HHIs, the HHIs of the remaining firms, modified by the hypothetical assumption that the merging firms were not participants, would be an appropriate set of supplementary HHIs, along with the usual market HHIs for the two markets. ${ }^{17}$ Removing the impact of each of the

\footnotetext{
162010 Horizontal Merger Guidelines § 6.1.

17 For example, if the pre-merger market has 5 firms, each with a share of $20 \%$, then the market $\mathrm{HHI}$ is 2000 . The market absent the merging firm would have 4 firms, each with a share of $25 \%$. This modified $\mathrm{HHI}$ level would be 2500 . These measures also are correlated in that relatively low standard $\mathrm{HHI}$ plus low market shares of the merging parties would lead to a relatively low modified $\mathrm{HHI}$.
} 
merging firms would be more relevant to the vulnerability of the market to coordination adverse to the non-merging firms, if either the upstream firm withdrew its inputs from the downstream firms' rivals, or if the downstream firm removed its demand from the upstream firms' rivals when there are no other buyers. These measures might then be relevant when evaluating input and customer foreclosure.

If the agencies are committed to formulating safe harbors based on these statistics, a combination of measures might be used. In particular, if both merging firms have low shares and the standard and modified HHIs in both markets also are below a certain level (e.g., the threshold for an unconcentrated market), the agencies could study whether they can conclude without further analysis that a vertical merger is unlikely to raise competitive concerns.

The following sections discuss potential competitive harms and benefits in more detail. ${ }^{18}$

\section{Competitive Harms}

Vertical mergers can harm consumers and competition in several ways, which this article classifies into the following categories: potential competition effects (Section 3); exclusionary effects (Section 5); unilateral effects (Section 6); coordinated effects (Section 7); evading regulation (Section 8); and facilitating harmful price discrimination (Section 9). The latter two categories involve the impact of the merger on the exercise of pre-existing market power, whereas the others involve achieving, enhancing or maintaining market power.

Because these effects can be overlapping and mutually reinforcing, this organizational structure is not unique. Some of the specific effects classified under a particular category could have been classified instead under another category. For example, an exclusionary effect may facilitate coordination or may be enhanced by the existence of coordination. Information exchanges can have both coordinated and exclusionary effects.

A vertical merger also may raise multiple concerns that involve effects in more than a single category. When the Vertical Merger Guidelines are revised, the agencies might choose to organize the categories differently or prioritize some of competitive concerns over others.

The 46 mergers challenged in the 1994-2013 period involved a variety of allegations of potential harm and some matters involved multiple categories of allegations. As listed

\footnotetext{
${ }^{18}$ We follow the Horizontal Merger Guidelines in discussing the harms before the benefits. This organization is not intended to reflect a presumption that the typical vertical merger likely is harmful.
} 
in the Appendix, elimination of potential competition was alleged in 9 matters, foreclosure in 35 matters, misuse of competitors' sensitive information to exclude in 22 matters, collusive information exchange in 11 matters, elimination of a disruptive buyer or other facilitating effects in 3 matters, and evasion of regulation in 2 matters. Unilateral effects and price discrimination were discussed but not specifically alleged as harms in any of the matters.

\section{Elimination or Reduction in Potential Competition}

A vertical merger can eliminate one of the merging firms as a potential entrant or facilitator of entry into the other firm's market. While these issues arise in a vertical merger, they can be construed as a type of unilateral horizontal concern, and so the agencies may have paid closer attention to this category of harm in the past.

\subsection{Merging Firms as Potential Entrants}

Pre-merger, either or both of the merging firms could be potential entrants into the other firm's market. Established firms competing in adjacent markets may be well-situated to enter because they may have expertise relevant to that market or easier access. The fear of entry by a customer or supplier may serve as a constraint on the pre-merger prices of a firm. The merger would reduce or eliminate this constraint. If either of the merging firms is the most likely perceived or actual potential entrant (or among a few most likely potential entrants) into the other's market, then the merged firm may be able to raise (or maintain supracompetitive) prices in the affected market.

Example: The DOJ's analysis of the Live Nation/Ticketmaster merger in 2010 raised potential competition concerns in that Live Nation was a potential entrant into ticketing. Ticketmaster also may have been a potential entrant into promotion and venues. ${ }^{19}$

Example: The FTC's enforcement action in 2013 against the Nielsen/Arbitron merger raised a somewhat different type of "future market" potential competition issue. While Nielsen sold TV audience data and Arbitron sold radio audience data, they apparently were both

${ }^{19}$ Competitive Impact Statement, United States v. Ticketmaster Entertainment, Inc., No. 1:10cv-00139 (D.D.C. Jan. 25, 2010), available at www.justice.gov/atr/cases/f254500/254544.pdf. 
potential entrants into the sale of "hybrid" (multimedia) audience data, an anticipated future market. $^{20}$

The following information would be particularly relevant to evaluating these potential competition concerns:

- Analysis of the pre-merger market structure in the upstream and downstream market, with a focus on whether either of the merging firms currently have significant market power and whether entry would make a material difference to competition.

- Evaluation of whether or not one or both of the merging firms are potential competitors (either actual or perceived potential entrants) into the market of the other, including any concrete plans for entry.

- Evaluation of whether or not there are sufficient other entrants equally wellpositioned to replace the loss of any potential competition provided by the merging firms.

\subsection{Merging Firms as Potential Entry Facilitators}

Rather than enter itself, each of the merging firms could facilitate entry by cooperating with or becoming a sponsor of potential entrants into the other firm's market. After the merger, the incentive to facilitate that entry might be eliminated. In fact, the firm might go further by refusing to deal with the new entrant or by creating incompatible products that would be unusable by an unintegrated entrant. ${ }^{21}$ Either way, potential entrants then would be forced to enter both markets simultaneously. Such a "two-level entry" requirement could reduce the likelihood of entry for several reasons, including potentially greater risk, higher sunk costs, higher minimum viable scale, or lack of expertise or other resources needed to successfully enter the additional market. By raising the cost, or reducing or eliminating the likelihood of entry, the merged firm may be able to raise or maintain supracompetitive prices in the affected market.

Example: The goal of the DOJ's original divestiture remedy proposal in the Microsoft case in 2000 was designed to create potential competition

\footnotetext{
20 Analysis Of Agreement Containing Consent Order To Aid Public Comment, In re Nielsen Holdings, N.V. and Arbitron, Inc., No. 131-0058 (F.T.C. Sept. 20, 2013), www.ftc.gov/sites/default/files/documents/cases/2013/09/130920nielsenarbitronanalysis.pdf.

${ }^{21}$ For this reason, this category of conduct could be classified as an exclusionary effect, as discussed infra Section 5 below.
} 
for a standalone Windows Operating System company by a divested Office Applications company. ${ }^{22}$

In addition to the information listed in Section 4.1 above, the following information would be relevant to evaluating these potential competition concerns:

- Information relevant to evaluating ease of entry and the degree to which potential entry is a significant constraint on pricing.

- Evaluation of whether and by how much simultaneously entry into both markets would create greater impediments to entry.

- Evaluation of whether either of the merging firms has plans or has made moves to facilitate or sponsor entry into the other firm's market.

\section{Exclusionary Effects}

Exclusionary effects have been one of the primary potential concerns arising in vertical mergers. ${ }^{23}$ Exclusionary effects can lead to harm not only to the downstream competitors, but also to the customers of the downstream firms.

Exclusionary effects can, under some circumstances, lead to harm to competitors in the form of higher input costs, but lower or unchanged downstream prices. A focus on consumer welfare would suggest that downstream effects would be necessary for enforcement from these exclusionary concerns, not merely harm to downstream competitors. As noted earlier, this policy issue would need to be resolved in the Vertical Merger Guidelines.

There are several mechanisms by which these exclusionary effects can occur. First, the merger could lead to input foreclosure, by which the upstream division of the merged firm refuses to sell, degrades quality, or raises the input prices charged to targeted (or all) rivals of the downstream division of merged firm, and thereby gives the downstream division the power to raise its price. The upstream division alternatively might threaten to deny access or degrade quality in order to increase its bargaining power to negotiate a higher input price.

Second, a merger could lead to customer foreclosure, by which the downstream division of the merged firm reduces or stops purchasing inputs from the other upstream firms, which

22 Plaintiffs' Memorandum in Support of the Final Judgment, IV.A.2, United States v. Microsoft Corporation, 97 F. Supp. 2d (D.D.C. Apr. 28, 2000) (No. 98-1232), available at www.justice.gov/atr/cases/f219100/219107.pdf.

${ }^{23}$ Exclusionary concerns also can arise in horizontal mergers. See 2010 Horizontal Merger Guidelines at $\S 6$. 
then can disadvantage those firms and provide the upstream division of the merged firm with the power to raise its price. Alternatively, the downstream division of the merged firm might threaten to refuse to purchase in order to induce the independent input suppliers to raise the prices that they charge to its downstream rivals.

These two types of foreclosure can function independently or can reinforce one another in combination. For example, if customer foreclosure leads to downstream rivals paying higher input prices, that effect will cause input foreclosure. Other markets also might be affected. For example, if downstream rivals are disadvantaged by input foreclosure and there are economies of scope with another product, the downstream division of the merged firm may gain the power to raise prices in that other product market, even though manufacturing that other product that does not use the input sold by the upstream division. This concern may be particularly relevant for high-technology markets.

Third, the merger could provide the downstream division of the merged firm with access to sensitive competitive information of its competitors from the upstream division of the merged firm, which the downstream firm can use to more rapidly respond to or even preempt competitive moves by these competitors, and deter such competitive moves as result. ${ }^{24}$

It is important to emphasize that the economic concept of foreclosure is not well gauged by simple "foreclosure rate" discussed in some antitrust cases. Foreclosure is substantial if it significantly increases the costs or restricts the output of the targeted victim, and its ability to expand in a cost-efficient way. Foreclosure thus can be substantial even if the rivals remain viable and even if they can achieve minimum efficient scale of production. Even if the simple foreclosure rate is low, the targeted firm may significantly lose competitiveness, for example, if the unrestrained substitutes are less efficient or if their producers lack sufficient capacity or have an incentive and ability to coordinate. Foreclosure also can lead to increased barriers to entry. By contrast, even if the simple foreclosure rate is high, rivals may not be significantly disadvantaged in the market if they have sufficient costeffective alternatives.

\subsection{Input Foreclosure}

A vertical merger can lead to the upstream division of the merged firm denying (i.e., refusing to sell) its input, degrading the quality of the input sold, or discriminating by raising the input price to one or more targeted non-merging firms. If the targeted rivals cannot substitute to other equally cost-effective inputs, their costs will be raised. This

\footnotetext{
${ }^{24}$ Access to competitively sensitive information can also facilitate coordination, as discussed in more detail infra Section 7.1.
} 
may occur if substitutes are inferior or more costly, or if the foreclosure conduct by the upstream firm gives the non-merging input producers unilateral or coordinated incentives to raise their prices. In addition, input foreclosure also might be used to disadvantage a maverick or disruptive downstream competitor and thereby facilitate coordination. ${ }^{25}$ If this foreclosure conduct materially raises the costs or reduces the quality of the targeted rivals, they would have the incentive to raise their quality-adjusted prices and reduce their output. If there are insufficient non-targeted competitors or other products that provide consumers with close substitutes, then the merging downstream firm will gain the ability to raise its price profitability. Fear of being targeted for input foreclosure also might deter entry. As a result, consumers and competition may be harmed.

The harmful effects in the downstream market may involve a unilateral price increase by the downstream division of the merged firm. In response, the targeted and other downstream rivals also typically would further raise their prices, which could cause further price increases by the downstream division. However, these harmful effects in the downstream market are not inevitable. Continued competition, expansion, and repositioning by non-targeted rivals, vertically-integrated competitors and other products may deter post-merger price effects.

Raising the price of the input generally would be more profitable than totally withholding access to the input or degrading its quality. ${ }^{26}$ Refusing to sell may be a second-best strategy when prices are regulated or price increases are constrained by most-favored nation provisions. Degrading quality also may be less detectable than price increases.

Example: In the AT\&T/McCaw merger in 1994, the DOJ's concerns amounted to a fear that AT\&T would engage in input foreclosure against McCaw's wireless competitors. ${ }^{27}$

Example: In the Google/ITA merger in 2011, the DOJ's input foreclosure concerns were that Google might withhold, degrade, or

\footnotetext{
25 This issue is discussed in more detail infra Section 7.3.

26 Threatening non-price foreclosure may be used to increase bargaining power, but end up being implemented temporarily when the bargaining process breaks down.

27 Competitive Impact Statement, United States v. AT\&T Corp., No. 1:94-cv-01555 (D.D.C. July 15, 1994), 59 Fed. Reg. 44,158, available at www.gpo.gov/fdsys/pkg/FR-1994-08-26/html/9420948.htm.
} 
raise the price of ITA's travel data to Google's competitors in a comparative flight search market. ${ }^{28}$

Example: In the Comcast/NBCU merger in 2011, the DOJ's and FCC's input foreclosure concerns were that the merged firm might withhold or raise the price of NBCU content to Comcast's MVPD competitors. ${ }^{29}$

The value of sales diverted to the downstream division of the merged firm leads to an incentive to raise the price of the upstream division of the merged firm. By raising the costs of targeted rivals, this will also cause upward pressure on their prices, holding other prices constant. The value of diverted sales and the upward pricing pressure generally will be higher when the diversion from targeted rivals to the downstream division of the merged firm is higher, and when the profit margin earned by the downstream division of the merged firm on incremental sales is higher.

In analyzing both input and customer foreclosure concerns, the following general market information would be relevant:

- Pre-merger market structure and competition in input and output markets.

- Impact of the merger on market structure and incentives in the input and output markets.

- Ability and incentive of non-merging input suppliers and downstream competitors to continue to compete, if foreclosed by merging firm.

- Behavior and market impact of other integrated firms.

- Existence, structure (including any exclusionary provisions), and competitive effects of other vertical contracts by the parties or other firms in the markets.

Beyond the general analysis of the markets, the following information also could aid in the evaluation of the potential upstream and downstream effects of input foreclosure:

- Identification of downstream rivals likely targeted for a foreclosure strategy of either raising price, refusing to sell, or degrading quality.

- Ability of the targeted downstream rivals to substitute to other equally cost-effective input suppliers and the capacity and incentives of those input suppliers, including any impact of any reduced input purchases by the downstream division of the merged firm.

${ }^{28}$ Competitive Impact Statement, United States v. Google, Inc., No. 1:11-cv-00688 (D.D.C. Apr. 8, 2011), available at www.justice.gov/atr/cases/f269600/269620.pdf.

${ }^{29}$ Competitive Impact Statement, United States v. Comcast Corp., No. 1:11-cv-00106 (D.D.C. Jan. 18, 2011), available at www.justice.gov/atr/cases/f266100/266158.pdf. 
- Determination of whether the other input suppliers would have the unilateral incentives to raise their prices, or the incentive and ability to raise prices in coordination with one another, if the upstream division of the merged firm were to engage in an input foreclosure strategy.

- The resulting extent to which downstream rivals' costs would be raised (or quality decreased) if the upstream division of the merged firm refuses to sell its input or raises its input price to the targeted downstream rivals.

- Evaluation of whether there are downstream firms (including vertically integrated competitors) that have alternative access to inputs from other upstream firms or upstream entry so that they will not be disadvantaged by (or targeted for) any foreclosure that occurs.

- Evaluation of the residual competitive constraints provided by these non-targeted downstream competitors.

- Evaluation of competitive constraints provided by other products that do not use the inputs supplied by the upstream division of the merged firm and its competitors.

- Information relevant to estimating the rate at which variable cost increases of the upstream and downstream are passed through as higher prices.

- Information from natural experiments relevant to estimating diversion ratios resulting from foreclosure.

- Input pricing and sales conduct of other integrated firms in the market and evaluation of any impact on downstream prices.

- Evaluation of the market impacts, if any, of other vertical contracts that involve exclusivity or favoritism.

\subsubsection{Gauging Input Foreclosure Effects}

When there is sufficient data available, input foreclosure incentives might be further scored with several quantitative methodologies.

\subsubsection{Vertical Arithmetic}

The vertical arithmetic methodology is a critical loss analysis that evaluates the profitability of a non-price foreclosure tactic such as refusing to deal with targeted rivals of the 
downstream division of the merged firm. ${ }^{30}$ The methodology compares the reduction in incremental profits borne by the upstream division from reducing its input sales to targeted firms versus the gains in incremental profits achieved by the downstream division when some of the sales of the targeted rivals are diverted to the downstream division. The data used for this methodology includes the incremental profit margins for the upstream and downstream divisions of the merged firm and the likely diversion from targeted downstream rivals to the downstream division in the event that the upstream division forecloses access of its input to those targeted rivals.

The vertical arithmetic methodology is most relevant where the concern is refusal to supply. However, a limitation of the methodology is that it evaluates only whether total foreclosure is profitable, not whether it is profit-maximizing or whether price increases might be more profitable than total foreclosure. When the foreclosure concern is an increase in price, rather than total foreclosure, the vertical arithmetic methodology also has only limited applicability. The vertical arithmetic methodology cannot determine the profitmaximizing price increase. It also does not use the information about demand elasticities that is inherent in the pre-merger profit margins. The methodology does not take efficiency benefits into account, nor does it permit balancing of harms against benefits.

\subsubsection{Vertical GUPPIs}

The vertical GUPPI methodology is designed to remedy the limitations of the vertical arithmetic. The vertical GUPPI methodology is based on the value of diverted sales and scores the direct impact of the vertical merger on the unilateral pricing incentives entailed by input foreclosure. ${ }^{31}$ The vGUPPI scores are analytically similar to the GUPPI scores defined implicitly in the 2010 Horizontal Merger Guidelines and are proportional to the profit-maximizing "first round" incentive to raise the prices. Two vGUPPl's are used to score the upward pricing pressure from the input foreclosure. The vGUPPlu gauges the incentive to raise the input prices of the upstream division of the merged firm to targeted downstream rivals. The vGUPPIr gauges the incentive of the targeted rivals to raise their downstream prices in response to the higher input price. ${ }^{32}$ When there are cognizable efficiency benefits or unilateral incentives to raise the price of the downstream division, the

${ }^{30}$ For the recent application in Comcast/NBCU, see Jonathan B. Baker et. al., The Year in Economics at the FCC, 2010-11: Protecting Competition Online, 39 REV. IND. ORG 297, 302304 (2011).

${ }^{31}$ Serge Moresi \& Steven C. Salop, vGUPPI: Scoring Unilateral Pricing Incentives in Vertical Mergers, 79 ANTITRUST L.J. 185 (2013).

${ }^{32}$ Id. Moresi and Salop suggest that the VGUPPIr is the more relevant measure because it relates more closely to the degree of potential consumer harm, as opposed to competitor harm. 
vGUPPIr also can be combined with the upward or downward pricing pressure from those effects, as scored by the vGUPPId. ${ }^{33}$

\subsubsection{Merger Simulation}

As with horizontal mergers, where there is sufficient data, merger simulation models sometimes are used to go beyond vertical arithmetic and vGUPPIs to quantify the equilibrium price effects of vertical mergers. Simulation models in principle can combine the analysis of both harms and benefits into a single structure to predict net effects in the upstream and downstream markets. For horizontal mergers, the 2010 Horizontal Merger Guidelines state that the agencies "do not treat merger simulation evidence as conclusive in itself, and they place more weight on whether their merger simulations consistently predict substantial price increases than on the precise prediction of any single simulation." ${ }^{34}$ For this purpose, the agencies typically will examine the assumed demand and econometric structure, the data, and the robustness of the estimates.

\subsubsection{Input Foreclosure Threats}

In situations where the upstream division of the merged firm negotiates prices with the downstream firms, the upstream firm might use the threat of foreclosure to negotiate higher prices from the rivals of the downstream firm. The credibility of the threat and bargaining power of the upstream division of the merged firm are increased by the merger because a failure to reach agreement with a downstream firm would harm the upstream firm less than it did absent the merger. This is because the profits of the downstream merging partner would increase if the agreement were not reached. This improved alternative for the merged firm generally allows the upstream firm to obtain a higher negotiated payment.

Example: Input foreclosure threats were analyzed by the DOJ and FCC in 2011 in the Comcast/NBCU merger, where the issue was the potential that Comcast might have the incentive to withhold or raise the price of NBCU programming to its MVPD rivals. ${ }^{35}$

Example: Foreclosure threats also were analyzed by the DOJ and FCC in 2004 in the News Corporation/DirecTV partial ownership acquisition,

\footnotetext{
33 The vGUPPId is discussed, infra Sections 5.1.1.2 and 10.1.

${ }^{34} 2010$ Horizontal Merger Guidelines § 6.1.

${ }^{35}$ Competitive Impact Statement, United States v. Comcast Corp., No. 1:11-cv-00106 (D.D.C. Jan. 18, 2011), available at www.justice.gov/atr/cases/f266100/266158.pdf.
} 
where the issue was the potential that News Corporation might have the incentive to withhold or raise the price of programming to its MVPD rivals. $^{36}$

This incentive to use input foreclosure threats to increase negotiated prices can be scored with an equilibrium bargaining analysis methodology that evaluates the impact of temporary or permanent reduction of supply on the profits of the upstream division of the merging firm and a targeted downstream firm. The methodology assumes that a larger relative impact on the profits of the downstream firm will lead to an increase in the negotiated payment, relative to the pre-merger price. $^{37}$

\subsection{Customer Foreclosure}

A vertical merger can lead to the merging downstream firm refusing to buy inputs from non-merging input suppliers. The strategy can disadvantage those upstream rivals and provide the upstream division of the merged firm with the power to raise its input price. Alternatively, the downstream division could use threats to foreclose to induce those input suppliers to raise the prices they charge its downstream rivals. This actual or threatened customer foreclosure also can create or reinforce input foreclosure by raising the costs of the downstream rival firms. ${ }^{38}$ As a result, downstream rivals and consumers may be harmed by the conduct.

Example: Although the FTC focused only the horizontal aspects of the case in 2014, the private litigation raised customer foreclosure as an issue in the St. Luke's/Saltzer merger. ${ }^{39}$

${ }^{36}$ The DOJ did not have a consent decree but relied on the FCC Order. Press Release, U.S. Dep't of Justice, Justice Department Will Not Challenge News Corp.'s Acquisition Of Hughes Electronics Corp. (Dec. 19, 2003), www.justice.gov/archive/opa/pr/2003/December/03_at_714.htm.

37 For a recent application, see Baker et. al. supra note 30 . As a simplification, the typical analysis often assumes a lump sum negotiated payment, not a per unit negotiated price that would lead to effects on the downstream market outcome. Under certain conditions where refusal to purchase by the merged firm would cause the negotiating seller to exit from the market, the merger might lead to the merged firm having to pay a higher price.

38 Threats of foreclosure are discussed in the 2010 Horizontal Merger Guidelines $\S 8$.

39 Findings of Fact and Conclusions of Law, Fed. Trad. Comm'n v. St. Luke's Health System, Ltd., No. 1:13-CV-00116 (Jan. 24, 2014), available at www.ftc.gov/system/files/documents/cases/140124stlukesfindings.pdf.. For the private case, see Saint Alphonsus Medical Center - Nampa, Inc. et al. v. St. Luke's Health System, Ltd., 2012 WL 6651167, * 4 (D. Idaho Dec. 20, 2012). This concern might be classified instead as input foreclosure in that the payers tend to be third-party insurance companies or managed care 
Example: Customer foreclosure concerns were raised by the FTC in 1997 in the Time Warner/Turner merger, regarding the possibility that Time Warner Cable would refuse to carry Fox News or MSNBC, which were competitors' to Turner's CNN network. ${ }^{40}$

Example: Customer foreclosure concerns were analyzed in the Comcast/NBCU merger by the FTC and FCC in 2011. The customer foreclosure issue was whether Comcast would carry competitors of NBCU.

The analysis of customer foreclosure would include an evaluation of the effects on upstream rivals if they are denied access to significant sales to the downstream division of the merged firm. The conduct can reduce their sales, which can lead them to exit or have higher costs, or reduce their incentive to invest. Either way, the upstream division of the merging firm may gain market power in the input market. In addition, because customer foreclosure can cause or reinforce input foreclosure, the information regarding input foreclosure also would remain relevant for the customer foreclosure concern as well.

The following specific information also could aid in the evaluation of the potential upstream and downstream effects of customer foreclosure concerns:

- Evaluation of whether the downstream division of the merged firm would have the ability to shift significant input purchases to the upstream division of the merged firm, and if so, determination of the resulting loss of sales to other upstream firms.

- Evaluation of the impact of those lost sales on the ability of one or more upstream firms to compete, and whether it might lead to the exit of any upstream firms, or higher costs, or reduction in investment incentives.

- Evaluation of whether the downstream division of the merged firm would have the power as a buyer to induce upstream firms to raise the input prices they charge to its downstream rivals (e.g., by threatening not to purchase).

- Whether non-merging upstream firms would have increased opportunities to sell additional inputs to non-merging downstream firms that might no longer wish to

operators, and that the patients are inputs who are steered to one or another hospital by the doctors. Where the merging firms produce complementary products, it is often possible to categorize the foreclosure either as input or customer foreclosure.

40 Time Warner Inc,123 F.T.C. 171 (1997), available at www.ftc.gov/system/files/documents/commission_decision_volumes/volume123/volume123a.pdf\#page=179. 
deal with the upstream division of the merged firm or would have very elastic demand for their inputs.

- Whether the upstream division of the merging firm or other upstream firms would gain the power to bargain for higher prices with the non-merging downstream firms.

- The resulting impact, if any, on the costs of non-merging downstream firms and downstream competition, as analyzed for input foreclosure.

- Purchase behavior of other integrated firms in the market and evaluation of any market impact.

- Evaluation of the market impacts, if any, of other vertical contracts that involve exclusivity or favoritism.

\subsection{Misuse of Competitors' Sensitive Information}

A vertical merger can lead to information transfers from rivals to the merging firm that might be misused strategically by the downstream division of the merged firm to preempt and thereby deter procompetitive actions by non-merging firms. ${ }^{41}$ If the merging firm obtains a rival's sensitive competitive information and uses it to respond more rapidly to the rival's moves with its own price decreases or product improvements, competition would seem to be benefited. However, this quick response actually would reduce the incentives of the rivals even to attempt the procompetitive moves, in that their first-mover advantages would be reduced. Thus, consumers may be harmed by the misuse of rivals' information.

Anticipating such misuse of its sensitive information, rivals might choose not to deal with the upstream division of the merged firm after the merger and instead purchase from more expensive or lower quality alternatives. In that case, the competitive harms in the downstream market from the misuse of competitors' sensitive would be replaced by the adverse competitive effects of the rivals essentially being forced by the merger to engage in what could be characterized as involuntary self-foreclosure.

Example: The FTC's remedies in 2010 of the Coca-Cola/CCE bottler merger and the parallel Pepsi bottler acquisitions focused on potential misuse of information about Dr. Pepper in a way that appeared to raise exclusion concerns. ${ }^{42}$

\footnotetext{
41 Coordinated effects from information exchanges are analyzed infra Section 7.1.

42 Analysis of Agreement Containing Consent Order to Aid Public Comment, In re The CocaCola Company, No. 101-0107 (F.T.C. Sept. 27, 2010), www.ftc.gov/sites/default/files/documents/cases/2010/09/100927cocacolaanal.pdf; Analysis of
} 
Beyond the general analysis of the market structure of the downstream and upstream markets, the following information would be relevant to the evaluation of misuse of competitors' sensitive information:

- Determination of whether the upstream division of the merged firm has premerger access to sensitive competitive information about downstream firms, such as advance notice of new products or new product specifications.

- Determination of whether the downstream division of the merged firm has premerger access to sensitive competitive information about upstream firms, such as prices and new products or technologies.

- Evaluation of whether the merged firm would be able to use this information to quickly respond or preempt competitive moves by its competitors.

- Determination of whether fear of this preemption likely would lead non-merging firms to avoid dealing with the merged firm, even if alternatives were more expensive or lower quality.

\section{Unilateral Competitive Incentives to Raise Downstream Prices}

A vertical merger may lead to a unilateral incentive for the downstream division to raise its price in order to increase the input sales and incremental profits of the upstream division. ${ }^{43}$ This incentive would occur in situations where the downstream division's rivals purchase inputs from the upstream division of the merged firm. This means that an increase in the price of the downstream division may lead in turn to those downstream firms purchasing additional inputs from the upstream division of the merged firm, which then would capture incremental profits on those sales. This incentive creates unilateral upward pricing pressure analogous to the unilateral effects of horizontal mergers, as discussed in the 2010 Horizontal Merger Guidelines. ${ }^{44}$

The unilateral incentives of the downstream division to raise price can be gauged in terms of the value of sales diverted to the upstream division of the merged firm in the event that the downstream division of the merged firm were to raise its price by a small, but

Agreement Containing Consent Order to Aid Public Comment, In re PepsiCo, Inc., No. 091-0133 (F.T.C. Feb. 26, 2010), www.ftc.gov/sites/default/files/documents/cases/2010/02/100226pepsicoanal.pdf.

${ }^{43}$ See Moresi and Salop, supra note 31.

${ }^{44} 2010$ Horizontal Merger Guidelines $§ 6.1$. 
significant, amount or to reduce its output. ${ }^{45}$ The unilateral incentive to raise the price of the downstream division of the merged firm generally will be higher if the market share of the upstream division of the merged firm is higher, if the profit margin earned by the upstream division of the merged firm on incremental sales is higher, and if the price of its input is a substantial fraction of the cost of the downstream firms. The upward pricing pressure from this unilateral incentive alternatively might be small or non-existent.

This unilateral incentive of the downstream division to raise its price may be mitigated or even reversed by a corresponding unilateral incentive to reduce its price as a result of taking into account in its pricing a lower real resource cost for the inputs purchased from the upstream division of the merging firm, what has been called "elimination of doublemarginalization." 46 The downward pricing pressure from elimination of doublemarginalization also alternatively might be small or even non-existent. ${ }^{47}$ Thus, while they are distinct, these two unilateral effects often are evaluated in tandem. Which incentive likely dominates depends on the facts of the merger. A profit-maximizing downstream division would view the overall company's "opportunity cost" of the input as reflecting the net effect of these two factors.

As in horizontal mergers, the upward pricing pressure may be offset by entry or repositioning by other competitors, though the exclusionary effects of foreclosure may reduce the likelihood of repositioning and entry.

When there is sufficient data available, the unilateral incentive to raise the downstream price can be gauged by analysis of diverted sales from the downstream division to the upstream division, if the downstream division were to raise its price and lose sales to other firms that purchase inputs from the upstream division. The vGUPPId scores the resulting upward pricing pressure of the price of the downstream division. ${ }^{48}$ This vGUPPId scores the value of diverted sales and depends on the upstream firm's incremental profit margin,

\footnotetext{
45 After the merger, the unintegrated rivals may not wish to purchase inputs from the upstream division of the merged firm. Substituting to other input suppliers may increase their costs and thereby create competitive concerns, as discussed supra Section 5.1.

46 This "elimination of double marginalization" efficiency claim is discussed infra Section 10.1.2.

47 There are several reasons why the effect might be small. First, the downstream division of the merging firm may not have the ability to use the inputs produced by the upstream division.

Second, the upstream division may be selling its inputs to the downstream division at a price equal to marginal cost in the pre-merger market. Third, the merged company may have a policy of each division treating other divisions at arms-length. Fourth, the elimination of double marginalization may not be found to be merger-specific. Elimination of double marginalization is analyzed in more detail along with analysis of other efficiency benefits in Section 10.
}

48 See Moresi and Salop, supra note 31. 
the share of the sales lost by the downstream firm that are diverted to other firms that purchase inputs from the upstream division of the merged firm, the magnitude of those likely incremental input purchases by the downstream rivals, along with input and output prices. The vGUPPId also can be extended to take into account the potential effects from elimination of double marginalization. ${ }^{49}$

Beyond the general analysis of the market structure of the downstream and upstream markets, certain information relevant to evaluating these unilateral pricing concerns would include the following:

- If the downstream firm raised price and lost a certain percentage of its sales, the fraction of those sales that would be diverted to other firms which would purchase inputs from the upstream division of the merged firm in order to satisfy their incremental demand.

- The likely increased input purchases from the diverted sales obtained by the upstream division.

- The incremental profit margin of the upstream division of the merged firm and the resulting incremental profits earned by the upstream division of the merged firm on those increased input purchases from the diverted sales.

- The incremental profit margin of the downstream division of the merged firm.

- The potential for repositioning by other downstream firms.

- The potential for rapid entry and longer term entry into the downstream market.

- Evaluation of the pricing behavior of other integrated firms.

\section{Coordinated Effects}

A vertical merger might raise several potential coordinated effects concerns in either the upstream market or the downstream market. ${ }^{50}$ First, a vertical merger may facilitate collusive interfirm information exchanges. Second, a vertical merger may facilitate coordination in the upstream market by eliminating the incentives of the downstream division of the merged firm to act as a disruptive buyer that deters coordination by upstream firms. Third, a vertical merger may facilitate coordination in the downstream market by weakening the disruptive behavior of a non-merging downstream firm. This

\footnotetext{
49 Id.

50 Vertical mergers potentially also could reduce the likelihood of coordination, as discussed infra Section 10.2.
} 
weakening of the maverick or disruptive firm can be implemented with targeted input foreclosure or threats of foreclosure. ${ }^{51}$ Fourth, a vertical merger could facilitate coordination by creating more symmetry in costs or placing the merged firm in a stronger position to punish defectors.

\subsection{Collusive Information Exchanges}

A vertical merger can lead to coordinated effects concerns by facilitating information exchanges between firms at the same level of production. The downstream division of the merged firm might share information about the prices of the upstream firms with the upstream division of the merged firm, and vice versa. In this way, consensus can be reached or detection lags can be reduced, both of which can facilitate coordinated effects or parallel accommodating conduct.

Example: The DOJ's analysis of the GrafTech/Seadrift merger in 2010 focused on collusive information exchanges, as possibly exacerbated by MFN provisions. ${ }^{52}$

Example: the FTC's analysis in 1998 of the Merck/Medco merger raised concerns about collusive information exchanges facilitated by the merger, as well as input foreclosure..$^{53}$

Relevant information for analyzing this concern includes the following:

- The vulnerability of each market to coordination. ${ }^{54}$

- Whether the downstream division's post-merger incentives will be to continue dealing with upstream firms other than its own upstream division.

- The pre-merger access by the downstream firms to sensitive competitive information about upstream firms, such as price information.

- The pre-merger access by the upstream firms to sensitive competitive information about downstream firms, such as price information.

\footnotetext{
51 As discussed in the exclusionary effects foreclosure, a vertical merger can facilitate coordination by non-merging firms in the upstream market in response to price increases by the upstream merging firm as part of an input foreclosure strategy.

52 Competitive Impact Statement, United States v. GrafTech Int'I Ltd., No. 1:10-cv-02039

(D.D.C. Nov. 29, 2010), available at www.justice.gov/atr/cases/f264600/264608.pdf

53 Analysis of Proposed Consent Order to Aid Public Comment, In re Merck \& Co., Inc. and Merck-Medco Managed Care, L.L.C., No. C-3853 (F.T.C. Aug. 27, 1998), www.ftc.gov/sites/default/files/documents/cases/1998/08/9510097ana.htm.

54 See 2010 Horizontal Merger Guidelines $§ 7.2$.
} 
- An explanation of how the merged firm would or would not be able to use this information to facilitate coordination after the merger.

- Evaluation of behavior of other integrated firms and its impact on the market.

\subsection{Elimination of Disruptive Buyer}

A vertical merger can facilitate coordination in the upstream market by eliminating the incentives of the downstream division of the merged firm to act as a disruptive buyer that deters coordination by upstream firms. ${ }^{55}$ After the merger, the merged firm might gain more net profits from that upstream coordination than it loses downstream by possibly having higher input costs. Where the downstream firm is a critical disruptive buyer in the pre-merger market and the upstream market is vulnerable to coordination, this concern could lead to higher input prices that would harm non-merging downstream firms and would be passed on to consumers as higher downstream prices.

The following information is relevant to the analysis of this concern:

- The vulnerability of the upstream market to coordination.

- Information regarding whether the downstream division of the merged firm is acting like a disruptive buyer regarding input purchases in the pre-merger market.

- Information regarding whether the downstream division of the merged firm is unique disruptive buyer or whether other buyers also act in this way.

\subsection{Weakening Maverick or Disruptive Competitive Behavior Downstream}

A vertical merger can facilitate coordination in the downstream market by weakening maverick or other disruptive competitive behavior of a non-merging downstream firm. ${ }^{56}$ If a non-merging firm is a maverick or otherwise disruptive competitive influence in the premerger market, the upstream division of the merged firm might weaken the incentives for that behavior by raising the price it charges to the disruptive firm or reducing its access to inputs. Alternatively, the downstream division might use customer foreclosure threats to induce upstream firms to raise their input prices charged to that disruptive firm.

\footnotetext{
55 These effects are similar to the analysis of the downstream division coercing non-merging upstream firms to raise prices to its downstream rivals, as discussed in Section 5.2.

56 There is not a similar concern about eliminating the downstream division of the merged firm acting as a maverick. If the downstream division of the merged firm were a maverick, there would be no incentive to use the merger to eliminate its maverick behavior, since the downstream division would be made worse off and the upstream division of the merging firm would not gain from downstream coordination.
} 
The mechanism for this concern can involve targeted input foreclosure or threats of foreclosure. ${ }^{57}$ As such, the analysis of this concern follows the analysis of input foreclosure set out above. In addition to the information generally relevant to evaluating foreclosure, the following information would be relevant to the analysis of this concern:

- The vulnerability of the downstream market to coordination.

- Information regarding whether one of the non-merging firms has been a maverick in the output market.

- Information regarding whether the merger would permit the upstream division of the merged firm to orchestrate higher input prices or other threats to deter this firm's maverick behavior.

\subsection{Using Lower Costs to Facilitate Consensus or Increase the Ability Punish Defectors}

A vertical merger might facilitate coordination by reducing the costs of the merged firm. First, if those lower costs could create more symmetry in costs and structure, it may lead to the firms' having similar desired prices. Second, obtaining lower costs also may place the merged firm in a stronger position to punish defectors, which can deter defection.

A significant policy issue involves the fact that challenging a merger based solely on this effect involves the agency attacking a merger because it reduces the costs of the merged firm. While the lower costs could facilitate coordination, the theory skates close to an "efficiency offense." As a result, the agencies might be reluctant to include it in a revision to the Vertical Merger Guidelines, except perhaps as a rarely applicable issue.

Example: This effect was alleged in 2001 in the Premdor/Masonite merger case. The DOJ's Competitive Impact Statement made the point that the merger would reduce the costs of the merged firm and lead to greater cost symmetry between the merged firm and the other vertically integrated firm. ${ }^{58}$

The following information would be relevant to evaluation of this cost-symmetry concern:

- Evidence regarding whether the downstream market is vulnerable to coordination.

\footnotetext{
57 Because this mechanism involves input foreclosure, it also could be classified as an exclusionary effect.

58 Competitive Impact Statement, United States v. Premdor, Inc., No. 1:01-cv-01696 (D.D.C. Aug. 3, 2001), available at www.justice.gov/atr/cases/f9000/9017.pdf.
} 
- Determining whether the merger increases cost symmetry by reducing costs.

- Determining if lower costs would significantly increase the ability and incentive to punish defectors from a coordinated agreement or informal understanding.

- Evaluating whether the downward pricing pressure from unilateral effects is more or less significant than the potential upward pricing from any increased likelihood of coordination.

\section{Evasion of Regulation}

A vertical merger might be used to evade price regulation. This concern raises a potential legal issue. In light of the Court's analysis in cases like Discon ${ }^{59}$ and Credit Suisse ${ }^{60}$ it is not entirely clear the extent to which evasion of regulation remains a viable antitrust cause of action or what limits are placed on the cause of action. Revisions to the Vertical Merger Guidelines would need to resolve this issue. This resolution may depend on whether the merger leads to foreclosure or coordination in addition to pure evasion of the price ceilings intended by the regulations. It also might depend on whether the regulations preempt antitrust laws entirely. It also might depend on and whether successful evasion could be rapidly detected and counteracted by the regulatory agency, whether the regulatory agency has the statutory and practical ability to punish evasion, and whether any regulatory impediments can be resolved by the regulator as part of its own merger approval process.

Example: The classic example is the pre-divestiture behavior of AT\&T, which allegedly used its purchases of equipment at inflated prices from its owned subsidiary, Western Electric, to artificially increase its costs and so justify higher regulated prices. ${ }^{61}$

Example: Potential evasion of regulation concerns were raised in the FTC's analysis in 2008 of the Fresenius/Daiichi Sankyo exclusive sublicense for a Daiichi Sankyo pharmaceutical used in Fresenius' dialysis clinics, which potentially could allow evasion of Medicare pricing regulations. ${ }^{62}$

\footnotetext{
59 Nynex Corp. v. Discon, Inc., 525 U.S. 128 (1998).

${ }^{60}$ Credit Suisse Securities (USA) LLC v. Billing, 551 U.S. 264 (2007).

61 United States v. AT\&T, 524 F. Supp. 1336, 1370-75 (D.D.C. 1981)

62 In the Matter of Fresenius Medical Care AG \& Co. KGaA and Daiichi Sankyo Company, Ltd, No. $081-0146$ (F.T.C. Sept. 15, 2008), available at www.ftc.gov/sites/default/files/documents/cases/2008/09/080915freseniusanal.pdf.
} 
The following information would be relevant to analysis of regulatory evasion concerns:

- Identification of any regulation of the prices or other competitive instruments of either of the merging firms.

- Determination of whether or not the merger could be used to evade that regulation, for example, whether cost-plus pricing regulation of the downstream firm could be evaded by raising the input price charged by the upstream division of the merged firm, or whether the regulations could be evaded by selling the products of the merging firms on a bundled basis.

- Evaluation of whether the evasion would be so costly to the merged firm that it would be unprofitable.

- Evaluation of whether the regulatory agency has the ability to review the merger and assess the merger's potential impact on regulatory evasion itself.

- Evaluation of whether rapid detection and penalties levied by the regulatory agency would deter attempted regulatory evasion.

\section{Harmful Price Discrimination}

A vertical merger might permit a firm with pre-existing market power to price discriminate more effectively in the downstream market and harm a targeted groups of consumers. ${ }^{63}$ To price discriminate, a firm must be able to identify targeted customers and prevent arbitrage. As noted in the 2010 Horizontal Merger Guidelines, this sometimes can be done by creating product differences and pricing plans that lead consumers to self-sort while preventing effective arbitrage. ${ }^{64}$ By doing so, the merged firm in effect may gain additional market power over the targeted consumer group. ${ }^{65}$

This concern raises two potential legal and policy issues. First, if a vertical merger leads to lower prices for some consumers and higher prices for others, the consumers targeted for the price increase likely would comprise a separate market under the

\footnotetext{
${ }^{63}$ More effective price discrimination does not always harm consumers. It is possible that it would permit a new product to be introduced. Sometimes it could lead to lower prices for some consumers without raising the prices to other consumers. These types of beneficial price discrimination would represent an efficiency benefit.

642010 Horizontal Merger Guidelines §3.

65 The agencies would explain how competition for the targeted consumer group is lessened by eliminating their ability to benefit from the competition for the non-targeted consumers.
} 
hypothetical monopolist test. ${ }^{66}$ Therefore, there is a legal issue of whether the benefits to the other consumers could be counted under Philadelphia National Bank. The policy issue is partially resolved in the 2010 Horizontal Merger Guidelines according to whether the benefits are inextricably linked and large, relative to the harms. However, this analysis may involve significant analytic and empirical difficulties in determining whether more effective price discrimination will be harmful or beneficial.

Second, this concern involves the merger leading to the increased exercise of preexisting market power, rather than achieving or maintaining market power. It sometimes has been argued that tying should be attacked only when it extends or maintains the market power of the tying product, rather than when it simply permits the firm to exercise its market power more fully. ${ }^{67}$ However, in the case of a merger, the agencies would be challenging the merger that facilitates the exercise of market power through price discrimination, not the price discrimination itself.

Example: Price discrimination concerns were raised by the DOJ in 1995 in its review of the Sprint/Deutsche Telecom joint venture. ${ }^{68}$

The following information would be relevant to the evaluation of harmful price discrimination concerns:

- Evaluation of whether the merger would facilitate customer sorting or prevent arbitrage by increasing information or by bundling the sale of complementary products.

- Evaluation of whether the discrimination likely would lead to lower prices for some consumers, and if so, the relative impacts on each group, or whether the discrimination likely would lead to lower prices for all consumers.

- Evaluation of whether the discrimination likely would lead to higher or lower total output.

\footnotetext{
66 This article follows the 2010 Horizontal Merger Guidelines $\S 10$ in focusing on harm to consumers, rather than total welfare. As stated there, "the Agencies are mindful that the antitrust laws give competition, not internal operational efficiency, primacy in protecting customers."

67 See, e.g., Dennis W. Carlton \& Ken Heyer, Extraction v. Extension: The Basis for Formulating Antitrust Policy Towards Single-Firm Conduct, 4 COMPETITION POL'Y INT'L 285, $298(2008)$

${ }^{68}$ Competitive Impact Statement, United States v. Sprint Corp., No. 95-cv-1304 (D.D.C. July 13,1995), available at www.justice.gov/atr/cases/f0400/0452.pdf.
} 


\section{Competitive Benefits}

A vertical merger may generate cognizable efficiency benefits that can lead to increased competition and, as a result, reverse potential anticompetitive impacts or deter the conduct that raises those concerns. In markets that are vulnerable to coordination, a vertical merger might reduce the likelihood of coordinated effects by the creation or enhancement of a maverick, or it might disrupt oligopoly coordination by decreasing the incentives to coordinate.

\subsection{Cognizable Efficiency Benefits}

A vertical merger potentially can generate a variety of efficiency benefits from vertical cooperation that improves communication flows and harmonizes the incentives of the merging firms. The benefits can include cost reductions and improved product design that can lead to lower prices, higher quality products, and increased investment. By reducing the cost of inputs used by the downstream division of the merged firm, a vertical merger also can create incentives for price reductions.

A typical vertical merger often is presumed to have greater efficiency benefits than a typical horizontal merger. However, there are many situations where vertical integration does not lead to efficiency benefits. Some types of efficiencies also may be more difficult to achieve than in a horizontal merger because the acquiring firm may lack expertise about the technology and business of the acquired firm. Thus, it cannot be assumed that significant cognizable efficiencies would occur in every vertical merger. Nor can it be assumed that efficiencies likely would be sufficient to reverse likely competitive harms.

In deciding whether efficiency benefits are cognizable, the analysis would follow the Horizontal Merger Guidelines in evaluating whether the claimed efficiencies are mergerspecific, verifiable, and involve procompetitive effects.

\subsubsection{Cost and Quality Efficiencies}

By reducing costs or increasing quality, the merged firm would obtain a unilateral incentive to reduce its quality-adjusted prices, all else held constant. This downward pricing pressure could offset or reverse the upward pricing pressure from the various sources of harms. Evaluation of these efficiencies would largely be the same as in the context of horizontal mergers.

The following information would be relevant to evaluating this issue:

- If other firms in the market are integrated, evaluation of whether those integrated firms are generally more efficient and why. 
- Identification of any expertise about the market by the downstream division of the merged firm that can be better shared with the upstream division of the merged firm if they are merged, or vice versa.

- Explanation of whether and how information flows will improve if the firms are merged.

- Explanation of any practical impediments to achieving these benefits absent the merger.

- Evaluation of whether any of these effects would lead to higher costs or reduced quality or services provided to other firms.

- Evaluation of any possible cost increases or other inefficiencies created by vertical integration, such as inefficient favoritism of inputs sold by the upstream division or greater complexity in dealing with firms that are now competitors.

- Evaluation of whether these benefits would be sufficient to reverse the potential for competitive harms.

\subsubsection{Elimination of Double Marginalization}

Vertical mergers may lead to efficiency benefits when the upstream division of the merged firm charges a pre-merger price to the downstream division that exceeds its marginal costs. In this situation, the merger can lead the downstream division to treat the real resource cost of this input as equal to the marginal cost, regardless of the nominal input price charged by the upstream division. That reduction in the perceived real resource cost of the input can lead to the incentive to reduce its downstream prices. Economists refer to this mechanism by the term "elimination of double marginalization."

It is sometimes argued that this prospect of this downward pricing pressure from elimination of double marginalization is a strong policy rationale to forgo all, or almost all, enforcement actions against vertical mergers. However, there are a number of strong economic reasons why elimination of double marginalization may be insufficient to trump the anticompetitive harms in some cases.

First, the downstream division's opportunity cost may not equal marginal cost. This reason relates to the unilateral incentives of the downstream division of the merged firm to raise price as a way to increase the profits of the upstream division. As discussed above, this incentive flows from the benefits to the upstream division of selling more 
inputs to rivals when the downstream division raises it price. ${ }^{69}$ This effect can reduce or reverse the effects of elimination of double marginalization.

Second, the upstream division of the merged firm and downstream division of the merged firm already may have a complex contract or relationship in the pre-merger world which already reduces or eliminates double marginalization. This may involve a two-part tariff or complex pricing such that the downstream firm pays a price equal to or close to marginal cost on incremental units. Alternatively, it may involve quantity-forcing purchase requirements that lead to equivalent results.

Third, elimination of double marginalization benefits may not be merger-specific. It may be practical to arrange a contract as described above that achieves this benefit in the future without the merger.

Fourth, it may not be economical for the downstream division of the merged to use the inputs of the upstream division of the merged firm because of product incompatibility or other reasons, in which case double marginalization would not be eliminated. ${ }^{70}$

Fifth, agency costs may lead some integrated companies to have their divisions treat one another at arm's length, in order to dampen competition or to compensate executives according to their performance and maintain the managerial efficiency of each division, which again would suggest that double marginalization would not be eliminated.

All these reasons would suggest a policy by which this factor should be evaluated on a case-by-case basis along with other potential efficiency benefits and weighed against the prospect of competitive harms, just as is done for horizontal mergers.

Example: In Comcast/NBCU, both the FCC and the DOJ were skeptical of the claims that the merger would eliminate double marginalization because of premerger contractual terms and the opportunity cost (unilateral incentives) issue.

Example: In AT\&T/McCaw, McCaw's existing network infrastructure was incompatible with AT\&T's network equipment, so any elimination of double marginalization effect would be delayed. ${ }^{71}$

In some cases, these effects might be predicted from natural experiments arising from previous vertical mergers. When there is sufficient data available, elimination of double

\footnotetext{
69 Supra Section 6.

${ }^{70}$ For example, See Enghin Atalay et. al., Vertical Integration and Input Flows, 104 AM. ECON. REV. 1120 (April 2014).

71 Competitive Impact Statement, United States v. AT\&T Corp., No. 1:94-cV-01555 (D.D.C. July 15, 1994), available at www.gpo.gov/fdsys/pkg/FR-1994-08-26/html/94-20948.htm.
} 
marginalization effects can be estimated and combined with the vGUPPId arising from the unilateral pricing incentives of the downstream division of the merged firm in order to evaluate the direction and magnitude of the net effect. ${ }^{72}$

The following information would be relevant to evaluating elimination of double marginalization benefits claims:

- Identification of whether the upstream division of the merged firm sells inputs to the downstream division of the merged firm.

- Determination of whether the downstream merged firm would have the ability and incentive to substitute away from input purchases from non-merging firms to the inputs of the upstream division.

- Identification of the pre-merger incremental profit margin on input sales by the upstream division of the merged firm to the downstream division of the merged firm, in order to measure the potential magnitude of the beneficial effect.

- Identification of whether the firms currently have a complex contract (e.g., with a two-part tariff or quantity-forcing provisions) that reduces or eliminates double marginalization inefficiencies.

- If they do not currently have such a contract, explanation of the reasons why the firms were unable to negotiate one and whether there are impediments other than the prospect of the merger to implementing such a complex contract in the future.

- If the upstream merging firm already is integrated in other ways, determination of the way in which inputs are priced to downstream divisions and how downstream divisions take those input costs into account in their decision-making.

- Evaluation of whether the merged firm's incentive to reduce the downstream price would be mitigated (or even reversed) by the fact that a reduction in the downstream price would reduce the profits earned by the upstream division of the merged firm on input sales to other downstream firms.

- Evaluation of the internal transfer prices and pricing practices of other integrated firms in the industry.

72 Supra Section 6. 


\subsubsection{Increased Investment Incentives}

Improved vertical cooperation from a vertical merger might lead to greater investment. One reason is that the merger can improve communication and coordination between firms at different levels of production. A merger also can "internalize" the spillover benefits that investment by one of the firms has on the profitability of the other. ${ }^{73}$ The merger also can spur investment by reducing the risk of hold-up. This risk can occur when one firm has to sink costs in anticipation of a long-term relationship with the other and there is fear of hold-up problems that cannot be resolved with a long term contract. In such cases, common ownership through a vertical merger may be necessary for the investments to be profitable. In rare circumstances, an improvement in the ability to price discriminate might facilitate a rapid increase in investment, so that consumers would be benefited on balance.

The following information would be relevant to evaluating this potential benefit:

- Determining the magnitude of the spillover effects.

- Determining why the parties have been unable to or cannot internalize these spillover effects with cost sharing or a limited joint venture, and whether that type of cost sharing or limited joint venture might create anticompetitive effects of its own.

- Identification of long-term investments that are subject to hold-up by its contracting partners.

- Evaluation of the impediments to eliminating this hold-up through contractual arrangements rather than a merger (e.g., transaction costs or inability to sufficiently specify contractual terms).

- Determination of the investment levels that would occur absent the merger.

- Evaluation of the harm to consumers and competition that would occur as a result of the reduced investment.

\footnotetext{
${ }^{73}$ For example, suppose that one of the firms has a potential investment that would cost $\$ 100$ and increase the NPV of its profits by $\$ 80$. Suppose it also would increase the NPV of the other firm's profits by $\$ 30$. The joint profits $(\$ 110)$ of this investment cover the investment costs $(\$ 100)$. However, the first firm would not be willing to undertake this investment unless the other firm shared the cost and such cost-sharing might face practical impediments. These impediments could include bargaining behavior and limited information and control, which can lead to free rider issues.
} 


\subsection{Reduced Likelihood of Coordination}

While a vertical merger can increase the likelihood coordination, ${ }^{74}$ it also may have the opposite effect in some circumstances and reduce the likelihood of coordination. The efficiency benefits of the merger or the structure of the merged firm may lead to the creation of a maverick firm. A vertical merger also may eliminate certain features of the pre-merger market that made successful coordinated behavior more likely.

The following information would be relevant to evaluating this potential procompetitive effect:

- Magnitude of merger-specific cost reductions or quality improvements, including elimination of double marginalization.

- Degree to which the pre-merger downstream market is vulnerable to or subject to coordination.

- Explanation of whether the elimination of downstream coordination would benefit the merged firm on balance.

- Evaluation of whether cost reductions or other benefits would increase the incentives of the merged firm to become a maverick in the downstream market.

- Explanation of whether the merged firm would have a greater ability to provide discounts without being detected, for example, by virtue of its participation in the downstream market as a vertically integrated firm.

- Explanation of whether the change in market structure would make it more difficult for other upstream firms to observe the merged firm's level of upstream output or price.

- Explanation of whether the merged firm would have a greater incentive to differentiate its product than before the merger.

- Evaluation of whether the merger would lead to greater cost asymmetry and thereby complicate reaching consensus on a coordinated price.

\section{Complementary Product Mergers}

The competitive effects analysis of complementary product mergers is very similar to the analysis of vertical mergers. As a matter of economics, the goods and services produced by firms at different levels of production (as in a vertical merger) are complements to one another. Complementary products sometimes are combined into

\footnotetext{
${ }^{74}$ See Section 7.
} 
packages and sold by one of firms, so they present as a vertical structure with the packaging firm treated as downstream. ${ }^{75}$ At other times, complementary products are sold separately and combined into packages by customers. In these cases, the identification of which product is upstream and which is downstream is a matter of convenience in explaining the theories of harms and benefits. ${ }^{76}$

The competitive concerns and benefits from complementary product mergers generally have straightforward analogues in the vertical merger context. ${ }^{77}$ However, some issues may be described differently or may present themselves with different conduct than they would in the context of a vertical merger. These differences can lead to confusion or controversy. ${ }^{78}$

Foreclosure concerns may involve conduct that appears different in form but is analytically identical or very similar. Like a vertical merger, a complementary products merger may involve a price increase for one of the components. However, the conduct might present itself differently as higher prices for purchasing the complementary products on an unbundled basis than for a bundle. Instead of an outright refusal to sell the upstream product, as may result from a vertical merger, a complementary products merger may involve a refusal to sell via post-merger product incompatibility. Or it may be implemented with physical or contractual tying, whereby the merged firm sells the

${ }^{75}$ For example, a customer planning a ski vacation can separately purchase the air travel, hotel, and lift ticket components separately or from a tour operator that does the packaging. Or, the customer might purchase the package from the airline, which separately purchases the hotel and lift ticket on a wholesale market.

${ }^{76}$ One seeming difference between the analysis of vertical and complementary product mergers is that a final customer may want to purchase only one of the complementary components. For example, the customer planning a ski vacation may drive to the resort and so have no need for an airline ticket. However, this also can occur in the vertical merger context. A downstream firm similarly may engineer its product so that it does not use the input produced by the upstream division of the merging firms or its direct competitors. For example, electrically powered automobiles do not use fuel injectors or spark plugs.

77 The potential competitive harms discussed here should be distinguished from the so-called "entrenchment theory" in complementary products mergers. Under that theory, the efficiencies from the transaction might lead the merged firm to capture sales from its rivals sufficient to cause those rivals to exit. See, e.g., FTC v. Procter \& Gamble, 386 U.S. 568 (1967). This "efficiencies offense" is no longer typically treated as a cognizable theory of harm in the U.S. See, e.g., Speech, Deborah Platt Majoras, Deputy Assistant Attorney General, Antitrust Division, GE-Honeywell: The U.S. Decision (Nov. 29, 2001), available at www.justice.gov/atr/public/speeches/9893.htm.

78 The proper characterization and treatment of complementary product mergers raised some controversy in the ABA Report at 8-9. 
one component to consumers only in a system or package with the other component produced by the merged firm.

Concerns about reduction in potential competition also can raise product incompatibility concerns in the complementary product merger context. To raise barriers to entry to firms that would produce only a single component, the merged firm might make its products incompatible with the likely designs of potential entrants or it might design proprietary interfaces.

In a complementary product merger where one of the firms assembles the products into a package to sell to consumers, elimination of double marginalization might be seen as identical as it would be in a vertical merger. In contrast, when complementary components are sold directly to consumers, the elimination of double marginalization may create an incentive for the merged firm to set lower prices only if the firms' complementary products are purchased as a bundle.

It has been suggested that enforcement policy towards complementary product mergers should be different, at least with respect to the exclusionary effects concerns. ${ }^{79}$ For example, it has been suggested that the agencies should wait and bring an enforcement action against anticompetitive exclusionary conduct under Section 1 or Section 2, only if and when the conduct is attempted in the future. This will be another policy issue that revised Guidelines will have to resolve.

While relying solely on post-merger enforcement might have appealing simplicity, it obscures several key facts that favor immediate enforcement under Section 7.

- The benefit of HSR review is to prevent the delays and remedial issues inherent in after-the-fact enforcement. Consumers would suffer harms during the interim until liability has been established and a remedy put into place. The ability of the merged firm to delay resolution of the matter could entail a long lag before the harm is remedied.

- There may be severe problems in remedying the concern. It may be too late to unwind the merger. Moreover, by the time the case reaches the remedy stage, the market structure may have irreversibly changed. Therefore, the only possible remedy might be for the antitrust agencies and the courts to engage in long term direct regulation of the prices, quality, and product designs of the merged firm, a task that they are not well-suited to undertake.

- Section 1 and Section 2 legal standards are more permissive than Section 7 standards. Those statutes do not reflect the incipiency and detection concerns

79 ABA Report at 8-9. 
that drove the adoption and implementation of Section 7. Those standards also may reflect greater concerns about deterring procompetitive unilateral conduct for a single entity, as well as concerns about the workability of remedies that are not present in the context of analyzing a merger. For example, administrative and other concerns that have led to more permissive Section 2 standards with respect to enforcing rules against anticompetitive refusals to deal. ${ }^{80}$ Some courts similarly have adopted standards for bundle pricing with above-cost safe harbors that are similar to predatory pricing standards and that would permit unbundled component price increases (i.e., bundle discounts) without fear of liability in markets with significant margins. ${ }^{81}$ Product incompatibility also might be subject to a very permissive standard unless it can be shown that the incompatibility lacks any efficiency benefits. ${ }^{82}$

- The agencies might well argue that anticompetitive post-merger conduct was caused by the merger agreement, so that it would be covered by Section 7 . However, this interpretation also might be a contentious issue with an uncertain outcome.

All in all, failure to address these kinds of issues in the context of merger review could lead to significant consumer harm and underdeterrence. Thus, there are strong policy reasons not to rely on post-merger enforcement for concerns that are raised by complementary product mergers. At the same time, pre-merger enforcement decisions ought to be based on inferences from reliable evidence, not speculation.

\section{Partial Ownership Acquisitions}

Partial acquisitions can raise competitive concerns when they involve vertical or complementary products. ${ }^{83}$ As with horizontal mergers, the analysis would examine the impact of the acquisition on the incentives of both firms and any exchanges of information entailed by the partial ownership interest. Even if the ownership interest is passive, competitive concerns may still occur as a result of the acquiring firm sharing in the profits of the acquired firm. For example, the downstream division still may have an incentive (albeit a somewhat reduced one) to raise its price, because some of the lost sales are now recaptured via increased input sales made by the upstream division. A

\footnotetext{
80 Verizon Communications v. Law Offices of Curtis V. Trinko, LLP, 540 U.S. 398, 414-15 (2004).

81 E.g., Cascade Health Solutions v. PeaceHealth, 515 F.3d 883 (9th Cir. 2008).

82 E.g., Berkey Photo v. Eastman Kodak Co., 603 F.2d 263, 287 (2d Cir. 1979).

832010 Horizontal Merger Guidelines $§ 13$.
} 
similar analysis would apply to price increases by the upstream division. A partial ownership interest also might affect the ability and incentive of the parties to achieve certain efficiency benefits. 


\begin{tabular}{|c|c|c|c|c|}
\hline \multicolumn{5}{|c|}{ Appendix: Vertical Merger Challenges (1994-2013) } \\
\hline Year & Case & Description & $\begin{array}{c}\text { Vertical Theory } \\
\text { of Harm }\end{array}$ & Remedy \\
\hline \multirow[t]{2}{*}{$\overline{2013}$} & $\begin{array}{l}\text { In re Nielsen } \\
\text { Holdings N.V. }\end{array}$ & $\begin{array}{l}\text { Nielsen Holdings N.V., a leading global media measurement } \\
\text { and research company that provided television, online, } \\
\text { mobile, and cross-platform measurement services, proposed } \\
\text { to acquire Arbitron Inc., a media measurement and research } \\
\text { company specializing in radio data. The FTC alleged that the } \\
\text { merger eliminated potential competition in the "future market" } \\
\text { of hybrid, cross-platform media data, because the two } \\
\text { companies were in the best position to develop these new } \\
\text { these new services. }\end{array}$ & $\begin{array}{l}\text { Merging firms as } \\
\text { potential } \\
\text { entrants; } \\
\text { merging firms as } \\
\text { entry facilitators }\end{array}$ & $\begin{array}{l}\text { Consent Decree required Nielsen (1) } \\
\text { to divest Arbitron's in-development } \\
\text { cross-platform audience } \\
\text { measurement business; and (2) to } \\
\text { perpetually license current and the } \\
\text { next eight years of data from } \\
\text { Arbitron's measurement panel to the } \\
\text { buyer. }\end{array}$ \\
\hline & $\begin{array}{l}\text { In re General } \\
\text { Electric Co.i }\end{array}$ & $\begin{array}{l}\text { General Electric Co. ("GE") proposed to acquire the aviation } \\
\text { business of Avio S.p.A., which designed and manufactured } \\
\text { component parts for aircraft engines, including parts used in } \\
\text { Pratt \& Whitney's engine for the Airbus A320neo. Through a } \\
\text { joint venture, GE manufactured the only other competing } \\
\text { engine option for the A320neo. The FTC alleged that GE } \\
\text { could disrupt the design and certification of the Avio-supplied } \\
\text { parts for the Pratt \& Whitney engine to favor the competitive } \\
\text { position of GE's own engine. }\end{array}$ & Input foreclosure & $\begin{array}{l}\text { Consent Decree incorporated portions } \\
\text { of the original contract between Avio } \\
\text { and Pratt \& Whitney regarding the } \\
\text { agreement to develop the engine } \\
\text { components and restricted GE from } \\
\text { interfering with the Avio team working } \\
\text { on the project. }\end{array}$ \\
\hline
\end{tabular}




\begin{tabular}{|c|c|c|c|c|}
\hline \multicolumn{5}{|c|}{ Appendix: Vertical Merger Challenges (1994-2013) } \\
\hline Year & Case & Description & $\begin{array}{c}\text { Vertical Theory } \\
\text { of Harm }\end{array}$ & Remedy \\
\hline \multirow[t]{2}{*}{2011} & $\begin{array}{l}\text { United States } \\
\text { v. Comcast } \\
\text { Corp. }{ }^{\text {iii }}\end{array}$ & $\begin{array}{l}\text { Comcast Corp., General Electric Co. ("GE"), NBC, and Navy, } \\
\text { LLC formed a joint venture of broadcast and cable network } \\
\text { assets. Comcast, the largest cable provider, would have } \\
\text { majority control of the JV containing NBC's popular video } \\
\text { programming. The DOJ and FCC alleged the combined } \\
\text { entity could withhold or raise the price of NBC content to } \\
\text { Comcast's rival multichannel video programming distributors } \\
\text { ("MPVDs") or online video programming distributors ("OVDs") } \\
\text { to reduce their ability to compete with Comcast, as Comcast } \\
\text { had done in the past with its RSN network. Additionally, } \\
\text { Comcast could refuse to carry competitor channels of NBC to } \\
\text { reduce their ability to compete against NBC. The DOJ } \\
\text { rejected claims that the transaction would eliminate double } \\
\text { marginalization as not, or at least not entirely, merger specific } \\
\text { because the industry had already successfully done so } \\
\text { through contracts with non-linear pricing. }\end{array}$ & $\begin{array}{l}\text { Input } \\
\text { foreclosure; } \\
\text { customer } \\
\text { foreclosure }\end{array}$ & $\begin{array}{l}\text { Final Judgment required the JV (1) to } \\
\text { license its broadcast, cable, and film } \\
\text { content to OVDs on terms comparable } \\
\text { to those on which it licensed to } \\
\text { MVPDs and to those the OVD } \\
\text { received from a competitor of the JV; } \\
\text { (2) to relinquish its voting rights in the } \\
\text { Hulu joint venture (an OVD); (3) to not } \\
\text { use certain restrictive license terms } \\
\text { with OVDs; (4) to not unreasonably } \\
\text { discriminate in the transmission of } \\
\text { lawful content through its internet } \\
\text { service, including by exempting its } \\
\text { own services from data caps; and (5) } \\
\text { to supply MVPDs with the JV's } \\
\text { programming content and submit to } \\
\text { binding arbitration over the license } \\
\text { terms. }\end{array}$ \\
\hline & $\begin{array}{l}\text { United States } \\
\text { v. GrafTech } \\
\text { International } \\
\text { Ltd. } .^{\text {iv }}\end{array}$ & $\begin{array}{l}\text { GrafTech International Ltd., a manufacturer of graphite } \\
\text { electrodes, proposed to acquire Seadrift Coke L.P., a } \\
\text { manufacturer of petroleum needle coke, a key input in the } \\
\text { graphite electrodes. The DOJ alleged it would provide } \\
\text { Seadrift with direct access to competitors' pricing and product } \\
\text { information through GrafTech's supply agreements and } \\
\text { most-favored-nation provisions with Seadrift's competitors, } \\
\text { particularly Conoco Phillips Co., ultimately facilitating the } \\
\text { collusive exchange of information. }\end{array}$ & $\begin{array}{l}\text { Collusive } \\
\text { information } \\
\text { exchanges }\end{array}$ & $\begin{array}{l}\text { Final Judgment required the } \\
\text { combined entity (1) to amend its } \\
\text { supply agreement to competitor } \\
\text { Conoco to remove ongoing audit } \\
\text { rights, sharing of confidential } \\
\text { information, and MFN pricing; (2) to } \\
\text { not enter into similar terms with } \\
\text { Conoco for ten years; and (3) to } \\
\text { firewall personnel deciding Seadrift's } \\
\text { pricing and production from Conoco's } \\
\text { competitively sensitive information. }\end{array}$ \\
\hline
\end{tabular}




\begin{tabular}{|c|c|c|c|c|}
\hline \multicolumn{5}{|c|}{ Appendix: Vertical Merger Challenges (1994-2013) } \\
\hline \multirow[t]{2}{*}{ Year } & Case & Description & $\begin{array}{c}\text { Vertical Theory } \\
\text { of Harm }\end{array}$ & Remedy \\
\hline & $\begin{array}{l}\text { United States } \\
\text { v. Google Inc. }\end{array}$ & $\begin{array}{l}\text { Google Inc. proposed to acquire ITA Software Inc., the } \\
\text { developer and licenser of QPX software, which was used by } \\
\text { airlines, travel agents, and online travel intermediaries } \\
\text { ("OTIs") to provide customized flight searches. Google } \\
\text { intended to offer an online travel search that would compete } \\
\text { with OTIs, many of which used QPX. The DOJ alleged that } \\
\text { Google could deny OTIs access to or raise their price for } \\
\text { QPX software. Additionally, the DOJ alleged that Google } \\
\text { could gain access to competitively sensitive information from } \\
\text { OTIs, such as tuning parameters and plans for new services. }\end{array}$ & $\begin{array}{l}\text { Input } \\
\text { foreclosure; } \\
\text { misuse of } \\
\text { competitors' } \\
\text { sensitive } \\
\text { information }\end{array}$ & $\begin{array}{l}\text { Final Judgment required Google (1) to } \\
\text { honor existing QPX licenses; (2) to } \\
\text { renew existing licenses under similar } \\
\text { terms and conditions; (3) to offer } \\
\text { licenses to other online travel } \\
\text { intermediaries on reasonable, non- } \\
\text { discriminatory terms and submit to } \\
\text { binding arbitration over those terms; } \\
\text { (4) to devote substantially the same } \\
\text { amount of resources to R\&D for QPX } \\
\text { as ITA did before the merger; (5) to } \\
\text { not use certain restrictive terms in its } \\
\text { agreements with airlines and OTIs; } \\
\text { and (6) to firewall OTIs' competitively } \\
\text { sensitive information from personnel } \\
\text { involved in Google's travel search } \\
\text { service. }\end{array}$ \\
\hline \multirow[t]{2}{*}{2010} & $\begin{array}{l}\text { In re Coca- } \\
\text { Cola Co. }{ }^{v i}\end{array}$ & $\begin{array}{l}\text { The Coca-Cola Co. ("Coke") proposed to acquire its largest } \\
\text { bottler, Coca-Cola Enterprises ("CCE"), and an exclusive } \\
\text { license to bottle and distribute all Dr. Pepper Snapple Group } \\
\text { ("Dr Pepper") brands that CCE formerly distributed. The FTC } \\
\text { alleged that to carry out distribution activities, Coke would } \\
\text { have access to Dr Pepper's commercially sensitive } \\
\text { information and could misuse that information to exclude } \\
\text { competitors or to facilitate collusion. }\end{array}$ & $\begin{array}{l}\text { Misuse of } \\
\text { competitors' } \\
\text { sensitive } \\
\text { information; } \\
\text { collusive } \\
\text { information } \\
\text { exchange }\end{array}$ & $\begin{array}{l}\text { Consent Decree limited access to Dr } \\
\text { Pepper's commercially sensitive } \\
\text { information to Coke employees who } \\
\text { perform traditional bottler functions. }\end{array}$ \\
\hline & $\begin{array}{l}\text { In re PepsiCo, } \\
\text { Inc. }\end{array}$ & $\begin{array}{l}\text { PepsiCo, Inc. proposed to acquire two of its bottler/distributor } \\
\text { companies and an exclusive license from Dr. Pepper } \\
\text { Snapple Group ("Dr Pepper") to bottle, distribute and sell } \\
\text { brands in certain territories that these two companies } \\
\text { formerly sold. The FTC alleged that to carry out distribution } \\
\text { activities, Pepsi would have access to Dr Pepper's } \\
\text { commercially sensitive information and could misuse that } \\
\text { information to exclude competitors or to facilitate collusion. }\end{array}$ & $\begin{array}{l}\text { Misuse of } \\
\text { competitors' } \\
\text { sensitive } \\
\text { information; } \\
\text { collusive } \\
\text { information } \\
\text { exchange }\end{array}$ & $\begin{array}{l}\text { Consent Decree limited access to Dr } \\
\text { Pepper's commercially sensitive } \\
\text { information to Pepsi employees who } \\
\text { perform traditional bottler functions. }\end{array}$ \\
\hline
\end{tabular}




\begin{tabular}{|c|c|c|c|c|}
\hline \multicolumn{5}{|c|}{ Appendix: Vertical Merger Challenges (1994-2013) } \\
\hline Year & Case & Description & $\begin{array}{c}\text { Vertical Theory } \\
\text { of Harm }\end{array}$ & Remedy \\
\hline & $\begin{array}{l}\text { United States } \\
\text { v. } \\
\text { Ticketmaster } \\
\text { Entm't, Inc. }^{\text {viii }}\end{array}$ & $\begin{array}{l}\text { Ticketmaster Entertainment, Inc., the largest U.S. primary } \\
\text { ticketing company, proposed to merge with Live Nation, Inc., } \\
\text { the largest concert promoter in the U.S. and the owner of } \\
\text { multiple concert venues. Before the merger, Live Nation had } \\
\text { licensed primary-ticketing technology from CTS Eventim AG } \\
\text { ("CTS") and secured contracts with venues representing } 15 \% \\
\text { of major concert venue capacity. The DOJ alleged a } \\
\text { horizontal loss of competition and potential competition for } \\
\text { primary ticketing services and vertical theories that the } \\
\text { merger would eliminate Live Nation and Ticketmaster as } \\
\text { facilitators of entry into one another's primary markets and } \\
\text { that the merger would allow Live Nation and Ticketmaster to } \\
\text { exclude competitors by bundling primary ticketing services } \\
\text { with access to artists promoted by Live Nation. The DOJ } \\
\text { rejected claims that the merger would eliminate double } \\
\text { marginalization as not merger specific, because the firms } \\
\text { were already in the process of becoming vertically integrated } \\
\text { themselves. }\end{array}$ & $\begin{array}{l}\text { Merging firms as } \\
\text { potential } \\
\text { entrants; } \\
\text { merging firms as } \\
\text { entry facilitators; } \\
\text { complementary- } \\
\text { product } \\
\text { foreclosure }\end{array}$ & $\begin{array}{l}\text { The DOJ required Ticketmaster (1) to } \\
\text { license its platform software used to } \\
\text { sell tickets to Anschutz Entertainment } \\
\text { Group, Inc. ("AEG") and give AEG the } \\
\text { option to acquire a copy of the source } \\
\text { code after four years; (2) to not ticket } \\
\text { AEG venues after four years to incent } \\
\text { AEG to take that option; and (3) to } \\
\text { divest its Paciolan "self-ticketing" } \\
\text { platform to Comcast-Spectator, L.P. }\end{array}$ \\
\hline 2008 & $\begin{array}{l}\text { In re } \\
\text { Fresenius } \\
\text { Medical Care } \\
A G \& \text { Co } \\
K G a A^{i x}\end{array}$ & $\begin{array}{l}\text { Fresenius Medical Care Ag \& Co. KGaA, a provider of } \\
\text { dialysis services and owner of dialysis clinics, proposed to } \\
\text { acquire an exclusive sublicense from Daiichi Sankyo } \\
\text { Company to manufacture and supply Venofer, an iron } \\
\text { deficiency treatment for dialysis patients, to independent } \\
\text { outpatient dialysis clinics in the U.S. The FTC alleged that } \\
\text { Fresenius could inflate its Medicare reimbursements by } \\
\text { increasing the prices it charged in its own clinics. Revisions } \\
\text { to Medicare reimbursement regulations taking effect in } 2012 \\
\text { would eliminate this distortion. }\end{array}$ & $\begin{array}{l}\text { Evasion of } \\
\text { regulation }\end{array}$ & $\begin{array}{l}\text { Consent Decree required Fresenius to } \\
\text { report an intra-company transfer price } \\
\text { below the level set by the FTC, which } \\
\text { was derived from current market } \\
\text { prices, until the revised regulations } \\
\text { took effect. }\end{array}$ \\
\hline
\end{tabular}




\begin{tabular}{|c|c|c|c|c|}
\hline \multicolumn{5}{|c|}{ Appendix: Vertical Merger Challenges (1994-2013) } \\
\hline Year & Case & Description & $\begin{array}{c}\text { Vertical Theory } \\
\text { of Harm } \\
\end{array}$ & Remedy \\
\hline & $\begin{array}{l}\text { United States } \\
\text { v. Monsanto } \\
\text { Co. }{ }^{x}\end{array}$ & $\begin{array}{l}\text { Monsanto Co., a leading provider of in-cottonseed traits, } \\
\text { proposed to acquire Delta and Pine Land Co. ("DPL"), a large } \\
\text { supplier of "traited cottonseed" that worked with biotech } \\
\text { companies to develop cotton seed traits. Monsanto and DPL } \\
\text { originally partnered to develop the most commonly used } \\
\text { "traited cottonseed," with Monsanto developing the traits and } \\
\text { DPL manufacturing the seeds and paying a license fee to } \\
\text { Monsanto. Before the merger, DPL had begun an effort to } \\
\text { replace Monsanto traits in DPL cottonseed with similar traits } \\
\text { developed by competitors of Monsanto. Monsanto had in } \\
\text { turn begun an effort to manufacture cottenseeds by acquiring } \\
\text { Stoneville Pedigree Seed Company ("Stoneville"), a } \\
\text { competitor of DPL. The DOJ challenged the merger, alleging } \\
\text { a horizontal loss of competition between DPL and Stoneville } \\
\text { and a vertical theory that DPL would refuse to partner with } \\
\text { other developers of cottonseed traits that would compete } \\
\text { against Monsanto's traits. }\end{array}$ & $\begin{array}{l}\text { Merging parties } \\
\text { as entry } \\
\text { facilitators; } \\
\text { customer } \\
\text { foreclosure }\end{array}$ & $\begin{array}{l}\text { Final Judgment required the merged } \\
\text { entity to divest certain promising } \\
\text { cottonseed development lines, trait } \\
\text { technology, and forty DPL cottonseed } \\
\text { breeding lines, and to modify } \\
\text { Monsanto's seed company licenses. }\end{array}$ \\
\hline
\end{tabular}




\begin{tabular}{|c|c|c|c|c|}
\hline \multicolumn{5}{|c|}{ Appendix: Vertical Merger Challenges (1994-2013) } \\
\hline Year & Case & Description & $\begin{array}{c}\text { Vertical Theory } \\
\text { of Harm }\end{array}$ & Remedy \\
\hline 2007 & $\begin{array}{l}\text { In re } \\
\text { Lockheed } \text { Martin Corp. }^{x i}\end{array}$ & $\begin{array}{l}\text { Boeing Corp., a global aerospace company and supplier to } \\
\text { the Department of Defense, and Lockheed Martin Corp., the } \\
\text { largest defense contractor in the U.S., were competing } \\
\text { providers of medium-to-heavy ("MTH") launch services and of } \\
\text { space vehicles. They proposed to form a joint venture to } \\
\text { consolidate their government launch-service and space- } \\
\text { vehicle businesses. The FTC alleged that the JV could } \\
\text { refuse to provide launch services to competing space vehicle } \\
\text { providers, in particular for packaged price procurement of the } \\
\text { two services known as "delivery in orbit." Additionally, the } \\
\text { FTC alleged that the companies might share confidential } \\
\text { information obtained through launch vehicle services with } \\
\text { their respective space vehicle businesses, and vice-versa. } \\
\text { The FTC also alleged that the transaction would lead to a } \\
\text { horizontal loss of competition between the merging parties' } \\
\text { MTH launch services and space vehicles, but accepted the } \\
\text { Department of Defense's finding that the increased launch } \\
\text { reliability would outweigh these effects. }\end{array}$ & $\begin{array}{l}\text { Input } \\
\text { foreclosure; } \\
\text { misuse of } \\
\text { competitors' } \\
\text { sensitive } \\
\text { information }\end{array}$ & $\begin{array}{l}\text { Consent Decree required (1) the JV } \\
\text { to cooperate on equal terms with all } \\
\text { providers of government space } \\
\text { vehicles; (2) Boeing and Lockheed to } \\
\text { equally consider the JV's launch } \\
\text { service competitors in government } \\
\text { delivery in orbit procurement; and (3) } \\
\text { the JV, Boeing, and Lockheed to } \\
\text { establish firewalls to prevent access } \\
\text { to one another's or third parties' } \\
\text { confidential information. }\end{array}$ \\
\hline 2003 & $\begin{array}{l}\text { United States } \\
\text { v. Northrop } \\
\text { Grumman } \\
\text { Corp. }^{\text {xii }}\end{array}$ & $\begin{array}{l}\text { Northrop Grumman Corp., one of two suppliers of certain } \\
\text { payloads for reconnaissance satellite programs, proposed to } \\
\text { acquire TRW, Inc., a company with the ability to act as a } \\
\text { prime contractor on reconnaissance satellite programs that } \\
\text { use these products. The DOJ alleged the company could } \\
\text { deny competitors access to its prime contractor or payload } \\
\text { capabilities. Additionally, it would provide the entity access to } \\
\text { proprietary information of rival prime and payload suppliers } \\
\text { contracting with Northrop. }\end{array}$ & $\begin{array}{l}\text { Complementary } \\
\text { products } \\
\text { foreclosure; } \\
\text { misuse of } \\
\text { competitors' } \\
\text { sensitive } \\
\text { information }\end{array}$ & $\begin{array}{l}\text { Final Judgment required Northrop (1) } \\
\text { to select payloads on a non- } \\
\text { discriminatory basis when it had } \\
\text { already been selected as the prime } \\
\text { contractor; and (2) to offer its } \\
\text { payloads to all competing prime } \\
\text { contractors on a non-discriminatory } \\
\text { basis when it was competing to be the } \\
\text { prime contractor. }\end{array}$ \\
\hline
\end{tabular}




\begin{tabular}{|c|c|c|c|c|}
\hline \multicolumn{5}{|c|}{ Appendix: Vertical Merger Challenges (1994-2013) } \\
\hline Year & Case & Description & $\begin{array}{c}\text { Vertical Theory } \\
\text { of Harm }\end{array}$ & Remedy \\
\hline \multirow[t]{2}{*}{2002} & $\begin{array}{l}\text { In re America } \\
\text { Online, Inc. }\end{array}$ & $\begin{array}{l}\text { America Online, Inc. (“AOL"), a global narrowband and } \\
\text { broadband internet service provider ("ISP"), proposed to } \\
\text { merge with Time Warner Inc., a cable television distributor } \\
\text { and broadband ISP. Before the merger, AOL had recently } \\
\text { launched AOL TV, a first-generation interactive television } \\
\text { ("ITV") service delivered through local cable providers. The } \\
\text { FTC alleged a horizontal loss of competition between AOL } \\
\text { and Time Warner in broadband internet access and vertical } \\
\text { theories that the combined firm would have the ability and } \\
\text { incentive to block or deter rival ITV providers from competing } \\
\text { with AOL TV through its cable system. Additionally, the FTC } \\
\text { was concerned that the merged entity would foreclose } \\
\text { competing ISPs from providing cable broadband ISP service } \\
\text { on Time Warner's cable system. }\end{array}$ & $\begin{array}{l}\text { Input } \\
\text { foreclosure; } \\
\text { customer } \\
\text { foreclosure }\end{array}$ & $\begin{array}{l}\text { Consent Decree required the merged } \\
\text { firm (1) to not make AOL broadband } \\
\text { available in a cable service area until } \\
\text { Earthlink, a competitor, was able to } \\
\text { offer cable internet service in that } \\
\text { area; (2) to enter agreements to carry } \\
\text { two other non-affiliated cable ISPs in } \\
\text { that area within } 90 \text { days of offering } \\
\text { AOL broadband service; (3) to not } \\
\text { interfere the ability of a subscriber to } \\
\text { access competing ITV services; and } \\
\text { (4) to charge a comparable price for } \\
\text { AOL DSL service in Time Warner } \\
\text { Service areas as outside those areas. }\end{array}$ \\
\hline & $\begin{array}{l}\text { In re Cytyc } \\
\text { Corp. }\end{array}$ & $\begin{array}{l}\text { Cytyc Corp., a manufacturer of liquid-based pap smear tests } \\
\text { for cervical cancer, proposed to acquire Digene Corp., the } \\
\text { only seller of a DNA-based test for human papillomavirus } \\
\text { ("HPV"). Doctors conducted HPV tests from the sample } \\
\text { obtained by the liquid-based pap smear. The FTC alleged } \\
\text { that Cytyc could foreclose its pap smear competitors by } \\
\text { limiting access to Digene's HPV test. The FTC also alleged } \\
\text { that the merger would eliminate Digene's incentive to } \\
\text { continue pursuing FDA approval for its HPV test to be used } \\
\text { as a primary cervical cancer screen in place of liquid-based } \\
\text { pap smears. }\end{array}$ & $\begin{array}{l}\text { Input } \\
\text { foreclosure; } \\
\text { merging parties } \\
\text { as potential } \\
\text { entrants }\end{array}$ & Transaction abandoned. \\
\hline
\end{tabular}




\begin{tabular}{|c|c|c|c|c|}
\hline \multicolumn{5}{|c|}{ Appendix: Vertical Merger Challenges (1994-2013) } \\
\hline Year & Case & Description & $\begin{array}{c}\text { Vertical Theory } \\
\text { of Harm }\end{array}$ & Remedy \\
\hline & $\begin{array}{l}\text { United States } \\
\text { v. Premdor } \\
\text { Inc. }\end{array}$ & $\begin{array}{l}\text { Premdor Inc., the largest global manufacturer of interior } \\
\text { molded doors and a small producer of molded door skins, } \\
\text { proposed to acquire Masonite Corp., a manufacturer of } \\
\text { molded door skins and fiberboard, the primary input for } \\
\text { molded door skins. Premdor had recently entered the } \\
\text { production of molded door skins and, although it was } \\
\text { relatively small, had used its potential to expand to negotiate } \\
\text { discounts from Masonite. The DOJ alleged a horizontal loss } \\
\text { of competition in the sale of molded door skins and vertical } \\
\text { theories that the elimination of the threat of Premdor's } \\
\text { expansion in molded door skins allowed enhanced } \\
\text { coordination upstream and downstream and that the merger } \\
\text { would lead to lower costs and greater cost symmetry } \\
\text { between the merged firm and another vertically integrated } \\
\text { firm, making collusion more likely. }\end{array}$ & $\begin{array}{l}\text { Merging parties } \\
\text { as potential } \\
\text { entrants; } \\
\text { elimination of } \\
\text { disruptive buyer; } \\
\text { collusive } \\
\text { information } \\
\text { exchanges; } \\
\text { using lower } \\
\text { costs to facilitate } \\
\text { consensus or to } \\
\text { increase the } \\
\text { ability to punish } \\
\text { defectors }\end{array}$ & $\begin{array}{l}\text { Final Judgment required Premdor to } \\
\text { divest its Towanda facility, which } \\
\text { engaged in the production of molded } \\
\text { door skins, creating a new upstream } \\
\text { competitor. }\end{array}$ \\
\hline 2001 & $\begin{array}{l}\text { In re Entergy } \\
\text { Corporation } \\
\text { and Entergy- } \\
\text { Koch, } L P^{\text {vvi }}\end{array}$ & $\begin{array}{l}\text { Entergy Corporation, a generator, transmitter, and distributor } \\
\text { of electricity, proposed to form a joint venture with Entergy- } \\
\text { Koch, LP with Koch Industries, Inc., which owned an } \\
\text { electricity derivatives trading company and the Gulf South } \\
\text { pipeline. The JV would combine Entergy's subsidiary that } \\
\text { markets electricity and gas with Koch Industries' electricity } \\
\text { derivatives trading company and the Gulf South pipeline. } \\
\text { The FTC alleged that, as a result of Entergy's exclusive legal } \\
\text { right to sell electricity in Louisiana and Mississippi and } \\
\text { recover } 100 \% \text { of the costs from those states' electricity } \\
\text { producers and the acquisition, Entergy would have the } \\
\text { incentive to purchase gas transportation services from the } \\
\text { Gulf South pipeline at an inflated price. }\end{array}$ & $\begin{array}{l}\text { Evasion of } \\
\text { regulation }\end{array}$ & $\begin{array}{l}\text { Consent Decree required Entergy to } \\
\text { establish a competitive bidding } \\
\text { process for its sourcing of gas } \\
\text { transportation services. }\end{array}$ \\
\hline
\end{tabular}




\begin{tabular}{|c|c|c|c|c|}
\hline \multicolumn{5}{|c|}{ Appendix: Vertical Merger Challenges (1994-2013) } \\
\hline Year & Case & Description & $\begin{array}{c}\text { Vertical Theory } \\
\text { of Harm }\end{array}$ & Remedy \\
\hline \multirow[t]{2}{*}{2000} & $\begin{array}{l}\text { In re Ceridian } \\
\text { Corp. }\end{array}$ & $\begin{array}{l}\text { Ceridian Corp., a provider of fleet-card services to over-the- } \\
\text { road trucking companies, acquired Trendar Corp, a provider } \\
\text { of fuel purchase desk automation systems used to process } \\
\text { fleet card transactions. The FTC alleged that Ceridian could } \\
\text { deny rival fleet-card services access to Trendar's system or } \\
\text { grant access to them only on discriminatory terms. The FTC } \\
\text { also alleged that Ceridian could deny rival fuel purchase desk } \\
\text { automation systems the ability to process Ceridian cards. } \\
\text { (The FTC learned of the non-reportable acquisition of } \\
\text { Trendar during Ceridian's } 1998 \text { acquisition of a competing } \\
\text { provider of fleet card services, which the FTC also } \\
\text { challenged.) }\end{array}$ & $\begin{array}{l}\text { Merging parties } \\
\text { as entry } \\
\text { facilitators; input } \\
\text { foreclosure; } \\
\text { customer } \\
\text { foreclosure }\end{array}$ & $\begin{array}{l}\text { Consent Order required Ceridian (1) } \\
\text { to provide ten-year licenses to } \\
\text { Trendar fuel purchase desk } \\
\text { automation systems to rival fleet-card } \\
\text { providers; (2) to pay for a third-party } \\
\text { software developer of the } \\
\text { Commission's choice to implement } \\
\text { interoperability between Trendar's } \\
\text { system and rival fleet-card providers' } \\
\text { networks; and (3) to provide ten-year } \\
\text { licenses to rival fuel purchaser desk } \\
\text { automation system suppliers to } \\
\text { process Ceridian's fleet cards on the } \\
\text { same terms as Trendar systems were } \\
\text { able to process Ceridian fleet cards. }\end{array}$ \\
\hline & $\begin{array}{l}\text { In re Boeing } \\
\text { Company }^{\text {viii }}\end{array}$ & $\begin{array}{l}\text { Boeing Company, a supplier of launch vehicles and a } \\
\text { contractor bidding for a certain classified Department of } \\
\text { Defense classified program, proposed to acquire certain } \\
\text { space-related assets of General Motors Corporation, } \\
\text { including satellite production and a systems engineering and } \\
\text { technical assistance ("SETA") for a certain classified } \\
\text { Department of Defense program. The FTC alleged that } \\
\text { Boeing would (1) use its position as the SETA contractor for } \\
\text { the classified program to favor its own bid or to obtain } \\
\text { competitively sensitive information about competitors' bids; } \\
\text { (2) access rival satellite producers' competitively sensitive } \\
\text { information through its launch vehicle business; (3) access } \\
\text { rival launch vehicle providers' competitively sensitive } \\
\text { information through its satellite business; and (4) withhold } \\
\text { satellite interface information necessary to use Boeing's } \\
\text { satellites with competing launch vehicles. }\end{array}$ & $\begin{array}{l}\text { Customer } \\
\text { foreclosure; } \\
\text { complementary } \\
\text { products } \\
\text { foreclosure; } \\
\text { misuse of } \\
\text { competitors' } \\
\text { sensitive } \\
\text { information }\end{array}$ & $\begin{array}{l}\text { Consent Decree required Boeing (1) } \\
\text { to firewall competitively sensitive } \\
\text { information of rival bidders it received } \\
\text { in its capacity as a SETA contractor; } \\
\text { (2) to provider certain documentation } \\
\text { and transition services to the } \\
\text { Department of Defense to enable it to } \\
\text { transition SETA for the program away } \\
\text { from Boeing; (3) to firewall } \\
\text { competitively sensitive information of } \\
\text { satellite rivals' obtained through } \\
\text { Boeing's launch services; and (4) to } \\
\text { provide certain interface information } \\
\text { for its satellites to rival launch services } \\
\text { providers. }\end{array}$ \\
\hline
\end{tabular}




\begin{tabular}{|c|c|c|c|c|}
\hline \multicolumn{5}{|c|}{ Appendix: Vertical Merger Challenges (1994-2013) } \\
\hline \multirow[t]{2}{*}{ Year } & Case & Description & $\begin{array}{c}\text { Vertical Theory } \\
\text { of Harm }\end{array}$ & Remedy \\
\hline & $\begin{array}{l}\text { United States } \\
\text { v. Enova } \\
\text { Corp. }^{\text {xix }}\end{array}$ & $\begin{array}{l}\text { Enova Corp., an electric utility provider in San Diego, and } \\
\text { Pacific Enterprises, a major provider of natural gas } \\
\text { transportation services to gas-fired plants and of natural gas } \\
\text { storage in California, proposed to merge. The DOJ alleged } \\
\text { that the Pacific would have the ability and incentive following } \\
\text { the merger to deny access to or raise the price of its natural } \\
\text { gas transportation services for rival electricity producers. } \\
\text { California regulations establishing marginal-unit pricing for all } \\
\text { electricity would magnify this effect. }\end{array}$ & Input foreclosure & $\begin{array}{l}\text { Final Judgment required the merged } \\
\text { firm to divest all low-cost gas } \\
\text { generators that would likely provide } \\
\text { the firm with the incentive to raise } \\
\text { electricity prices. It allowed Enova to } \\
\text { keep higher-cost generators because } \\
\text { these would be active insufficiently } \\
\text { frequently for a downstream increase } \\
\text { in price to outweigh an upstream loss } \\
\text { of sales. }\end{array}$ \\
\hline \multirow[t]{2}{*}{1999} & $\begin{array}{l}\text { In re Barnes \& } \\
\text { Noble, Inc. } \\
\text { and Ingram } \\
\text { Book Group }\end{array}$ & $\begin{array}{l}\text { Barnes and Noble, Inc. ("B\&N"), a book retailer, proposed to } \\
\text { merge with Ingram Book Group, a book wholesaler. Before } \\
\text { the transaction, B\&N had announced publicly that it } \\
\text { considered providing wholesale services to retailers. The } \\
\text { FTC alleged a horizontal loss of potential competition in book } \\
\text { wholesaling and vertical theory that B\&N could restrict } \\
\text { access or raise prices of books to competing retailers. The } \\
\text { FTC also alleged that B\&N would could gain access to rivals' } \\
\text { competitively sensitive information through Ingram which } \\
\text { could allow it to preempt rivals' competitive efforts. }\end{array}$ & $\begin{array}{l}\text { Input } \\
\text { foreclosure; } \\
\text { elimination of } \\
\text { potential } \\
\text { competition; } \\
\text { misuse of } \\
\text { competitors' } \\
\text { sensitive } \\
\text { information }\end{array}$ & Transaction abandoned. \\
\hline & $\begin{array}{l}\text { In re } \\
\text { Provident } \\
\text { Companies }^{x x i}\end{array}$ & $\begin{array}{l}\text { Provident Companies, Inc. and UNUM Corporation, both } \\
\text { providers of insurance for individual disability policies, } \\
\text { proposed to merge. It was common practice in the industry } \\
\text { for insurers to supply one another with actuarial data through } \\
\text { an industry association to assist in determining the risk of } \\
\text { individuals for particular injuries. The FTC alleged that the } \\
\text { combined firm would no longer have the incentive to provide } \\
\text { this data to rivals, as it would have sufficient scale that the } \\
\text { competitive harm to rivals would outweigh the reduction in its } \\
\text { own ability to assess its insureds' risk. }\end{array}$ & Input foreclosure & $\begin{array}{l}\text { Consent Decree required the merged } \\
\text { firm to provide its actuarial data to } \\
\text { rivals through an industry association } \\
\text { for } 20 \text { years. }\end{array}$ \\
\hline
\end{tabular}




\begin{tabular}{|c|c|c|c|c|}
\hline \multicolumn{5}{|c|}{ Appendix: Vertical Merger Challenges (1994-2013) } \\
\hline Year & Case & Description & $\begin{array}{c}\text { Vertical Theory } \\
\text { of Harm }\end{array}$ & Remedy \\
\hline & $\begin{array}{l}\text { In re Merck \& } \\
\text { Co, Inc. }\end{array}$ & $\begin{array}{l}\text { Merck \& Co., a pharmaceutical manufacturer, acquired } \\
\text { Medco Manage Care, L.L.C. in 1993, a provider of pharmacy } \\
\text { benefit management ("PBM") services. The FTC alleged that } \\
\text { Merck could (1) foreclose rival pharmaceutical manufacturers } \\
\text { from Medco's drug formulary; (2) Merck would have access } \\
\text { to competitors' proprietary information through the PBM } \\
\text { services; and (3) Medco would be eliminated as an } \\
\text { independent, disruptive negotiator with pharmaceutical } \\
\text { companies. }\end{array}$ & $\begin{array}{l}\text { Customer } \\
\text { foreclosure; } \\
\text { misuse of } \\
\text { competitors' } \\
\text { sensitive } \\
\text { information; } \\
\text { collusive } \\
\text { information } \\
\text { exchange; } \\
\text { elimination of a } \\
\text { disruptive buyer. }\end{array}$ & $\begin{array}{l}\text { Consent Decree required Merck: (1) } \\
\text { to establish an independent } \\
\text { Pharmacy and Theraputics committee } \\
\text { to determine which drugs would } \\
\text { qualify for an "open formulary" it was } \\
\text { required to maintain; (2) to accept all } \\
\text { discounts offered by other drug } \\
\text { manufacturers on the open formulary } \\
\text { and reflect those discounts in their } \\
\text { products' ranking on the open } \\
\text { formulary; and (3) to firewall from } \\
\text { Merck and Medco the competitively } \\
\text { sensitive information of the other's } \\
\text { rivals. }\end{array}$ \\
\hline & $\begin{array}{l}\text { In re CMS } \\
\text { Energy } \\
\text { Corporation }^{\text {xxiii }}\end{array}$ & $\begin{array}{l}\text { CMS Energy Corporation ("CMS"), which owned a } \\
\text { combination electric and gas utility serving broad sections of } \\
\text { Michigan, proposed to acquire the Panhandle Eastern and } \\
\text { Trunkline pipelines from Duke Energy. Before the merger, } \\
\text { CMS had natural gas interconnections with other rival } \\
\text { pipelines. The FTC alleged that CMS would have an } \\
\text { incentive to close its interconnection or reduce its } \\
\text { interconnection capacity available to other pipelines, } \\
\text { increasing demand on the Panhandle Eastern and Trunkline } \\
\text { pipelines and enabling them to raise their rates. }\end{array}$ & Input foreclosure & $\begin{array}{l}\text { Consent Decree required CMS (1) to } \\
\text { maintain a designated level of } \\
\text { interconnection capacity based on } \\
\text { historical usage levels; and (2) offer } \\
\text { shippers the ability to break contracts } \\
\text { and interconnect with another pipeline } \\
\text { or to tap CMS's own account to } \\
\text { supply gas if the available } \\
\text { interconnection capacity is less than } \\
\text { actual capacity. }\end{array}$ \\
\hline
\end{tabular}




\begin{tabular}{|c|c|c|c|c|}
\hline \multicolumn{5}{|c|}{ Appendix: Vertical Merger Challenges (1994-2013) } \\
\hline Year & Case & Description & $\begin{array}{c}\text { Vertical Theory } \\
\text { of Harm }\end{array}$ & Remedy \\
\hline & $\begin{array}{l}\text { United States } \\
\text { v. SBC } \\
\text { Comm'ns } \\
\text { Inc. } \text {. }^{x i v}\end{array}$ & $\begin{array}{l}\text { SBC Communications, Inc. ("SBC"), a provider of local } \\
\text { exchange, long distance, and wireless mobile telephone } \\
\text { services, proposed to acquire Ameritech Corporation, a } \\
\text { provider of wireless mobile telephone services. Before the } \\
\text { merger, Ameritech had planned to enter the provision of local } \\
\text { exchange and long distance services in a bundle with } \\
\text { Ameritech's wireless service in St. Louis. The DOJ alleged } \\
\text { that, as a result of the acquisition, Ameritech would no longer } \\
\text { have the incentive to offer a bundle of Ameritech's wireless } \\
\text { services with the local exchange and long-distance services } \\
\text { in competition with SBC. The DOJ also alleged a horizontal } \\
\text { loss of competition in markets where both SBC and } \\
\text { Ameritech provided wireless service. }\end{array}$ & $\begin{array}{l}\text { Merging parties } \\
\text { as potential } \\
\text { entrants; } \\
\text { complementary } \\
\text { product } \\
\text { foreclosure }\end{array}$ & $\begin{array}{l}\text { Final Judgment required SBC to } \\
\text { divest its cellular business and all } \\
\text { assets involved in its planned entry } \\
\text { into St. Louis, as well as assets to } \\
\text { eliminate the horizontal overlaps. }\end{array}$ \\
\hline & $\begin{array}{l}\text { In re } \\
\text { Dominion } \\
\text { Resources, } \\
\text { Inc. }\end{array}$ & $\begin{array}{l}\text { Dominion Resources, Inc., an electricity provider, proposed } \\
\text { to acquire Consolidated Natural Gas Co., a distributor of } \\
\text { natural gas, one of the fuels used to generate electricity. The } \\
\text { FTC alleged that Dominion could use its control over the } \\
\text { available source of natural gas and transportation capacity in } \\
\text { the area to limit or deter independent producers from } \\
\text { generating electricity. }\end{array}$ & $\begin{array}{l}\text { Merging parties } \\
\text { as entry } \\
\text { facilitators; input } \\
\text { foreclosure }\end{array}$ & $\begin{array}{l}\text { Consent Decree required the } \\
\text { divestiture of Consolidated's } \\
\text { subsidiary, Virginia Natural Gas, Inc., } \\
\text { which provided gas distribution } \\
\text { services. }\end{array}$ \\
\hline$\overline{1998}$ & $\begin{array}{l}\text { United States } \\
\text { v. Lockheed } \\
\text { Martin } \\
\text { Corp. }^{x x v i}\end{array}$ & $\begin{array}{l}\text { Lockheed Martin Corp. and Northrop Grumman Corp., both } \\
\text { integrated defense contractors, proposed to merge. The } \\
\text { DOJ alleged that the acquisition would give Lockheed control } \\
\text { over all of Northrop's military platforms, prime contracts, and } \\
\text { capabilities in critical systems and subsystems, providing it } \\
\text { with the incentive to refuse to sell, sell inferior quality, or sell } \\
\text { on unfavorable terms these systems to its integrated } \\
\text { electronics system competitors, and that Northrop's systems } \\
\text { engineering and technical assistance services contracts } \\
\text { would give Lockheed access to competitors' sensitive } \\
\text { information. The DOJ also alleged horizontal theories of } \\
\text { harm in other markets. }\end{array}$ & $\begin{array}{l}\text { Input } \\
\text { foreclosure; } \\
\text { misuse of } \\
\text { competitors' } \\
\text { sensitive } \\
\text { information }\end{array}$ & Transaction abandoned. \\
\hline
\end{tabular}




\begin{tabular}{|c|c|c|c|c|}
\hline \multicolumn{5}{|c|}{ Appendix: Vertical Merger Challenges (1994-2013) } \\
\hline Year & Case & Description & $\begin{array}{c}\text { Vertical Theory } \\
\text { of Harm }\end{array}$ & Remedy \\
\hline & $\begin{array}{l}\text { In re } \\
\text { PacificCorp }\end{array}$ & $\begin{array}{l}\text { PacifiCorp, a provider of retail electricity in seven states and } \\
\text { of wholesale electricity in others, proposed to acquire The } \\
\text { Energy Group PLC ("TEG"), which owned Peabody Coal } \\
\text { Company, a coal-mine operator. TEG supplied coal to the } \\
\text { Navajo and Mojave Generating Stations, which competed } \\
\text { with PacifiCorp's generating assets in the Western Systems } \\
\text { Coordinating Council, an electricity pool. The FTC alleged } \\
\text { that PacifiCorp would have an incentive (1) to manipulate the } \\
\text { costs of its coal to affect the contract prices to Navajo and } \\
\text { Mojave Generating Stations and refrain from offering them } \\
\text { discounts if the coal price were to fall or if its mines were to } \\
\text { have excess capacity; and (2) to access competitively } \\
\text { sensitive information about the costs of competitors using its } \\
\text { coal. }\end{array}$ & $\begin{array}{l}\text { Input } \\
\text { foreclosure; } \\
\text { misuse of } \\
\text { competitors' } \\
\text { sensitive } \\
\text { information }\end{array}$ & $\begin{array}{l}\text { Consent Decree required PacifiCorp } \\
\text { to divest Peabody Western Coal } \\
\text { Company, the subsidiary owning the } \\
\text { mines that supplied competitors. The } \\
\text { transaction was abandoned for } \\
\text { unrelated reasons. }\end{array}$ \\
\hline & $\begin{array}{l}\text { United States } \\
\text { v. Primestar, } \\
\text { Inc. } \text {.xviii }^{\text {. }}\end{array}$ & $\begin{array}{l}\text { Primestar, Inc., an investment entity controlled by five cable } \\
\text { companies, proposed to acquire the satellite assets of } \mathrm{MCl} \\
\text { Communications Corp., The News Corporation Limited, and } \\
\text { K. Rupert Murdoch, which included the only orbital slot from } \\
\text { which direct-broadcast service ("DBS") video programming } \\
\text { could be offered. The DOJ alleged that the acquisition would } \\
\text { allow the cable companies to deny the orbital slot to their } \\
\text { DBS competitors, preserving their cable monopolies. }\end{array}$ & Input foreclosure & Transaction abandoned. \\
\hline 1997 & $\begin{array}{l}\text { In re TRW } \\
\text { Inc.xxix }\end{array}$ & $\begin{array}{l}\text { TRW Inc. and BDM International Inc. proposed to merge. } \\
\text { TRW was part of a joint venture competing for the Ballistic } \\
\text { Missile Defense Organization's Lead Systems Integrator } \\
\text { ("LSI") contract while BDM was the sole supplier of systems } \\
\text { engineering and technical assistance ("SETA") services for } \\
\text { the program. The FTC alleged that the acquisition would } \\
\text { enable TRW to access its competitors' competitively sensitive } \\
\text { bidding information and that TRW's SETA role would allow it } \\
\text { to favor its own bids through the setting of procurement rules } \\
\text { and evaluation of bids. }\end{array}$ & $\begin{array}{l}\text { Customer } \\
\text { foreclosure; } \\
\text { misuse of } \\
\text { competitors' } \\
\text { sensitive } \\
\text { information }\end{array}$ & $\begin{array}{l}\text { Consent Decree required TRW to } \\
\text { divest BDM's contract with the } \\
\text { Ballistic Missile Defense Organization } \\
\text { for SETA services and all related } \\
\text { assets. }\end{array}$ \\
\hline
\end{tabular}




\begin{tabular}{|c|c|c|c|c|}
\hline \multicolumn{5}{|c|}{ Appendix: Vertical Merger Challenges (1994-2013) } \\
\hline Year & Case & Description & $\begin{array}{c}\text { Vertical Theory } \\
\text { of Harm }\end{array}$ & Remedy \\
\hline & $\begin{array}{l}\text { In re Shell Oil } \\
\text { Co. }{ }^{x x x}\end{array}$ & $\begin{array}{l}\text { Shell Oil Co. and Texaco, Inc. proposed to form a joint } \\
\text { venture combining their various gasoline, fuel, and pipeline } \\
\text { assets. Shell and another company made the majority of } \\
\text { asphalt used in Northern California, and both bought the } \\
\text { undiluted heavy crude used to make the asphalt from } \\
\text { Texaco's pipeline. The FTC alleged that the JV could raise } \\
\text { the cost of crude for Shell's competitor, leading to an } \\
\text { increase in the price for asphalt. The FTC also alleged } \\
\text { numerous horizontal theories of harm in other markets. }\end{array}$ & Input foreclosure & $\begin{array}{l}\text { Consent Decree required the JV to } \\
\text { enter into a ten-year supply } \\
\text { agreement with Shell's competitor for } \\
\text { crude and to divest assets to remedy } \\
\text { the horizontal overlaps. }\end{array}$ \\
\hline & $\begin{array}{l}\text { In re Cadence } \\
\text { Design } \\
\text { Systems, } \\
\text { Inc. } \text {.xxi }^{\text {xis }}\end{array}$ & $\begin{array}{l}\text { Cadence Design Systems, Inc. ("Cadence"), a leading } \\
\text { supplier of integrated circuit layout environments, proposed } \\
\text { to acquire Cooper \& Chryan Technology, Inc. ("CCT"), a } \\
\text { supplier of integrated circuit routing tools. The FTC alleged } \\
\text { that the merger would reduce Cadence's incentives to permit } \\
\text { competing suppliers of routing tools to access its layout } \\
\text { environments on the same terms as it allowed developers of } \\
\text { tools which did not compete with CCT's. }\end{array}$ & Input foreclosure & $\begin{array}{l}\text { Consent Decree required Cadence to } \\
\text { allow developers competing with CCT } \\
\text { to participate in its software interface } \\
\text { programs on the same terms as } \\
\text { developers whose tools did not } \\
\text { compete with CCT's. }\end{array}$ \\
\hline & $\begin{array}{l}\text { In re Time } \\
\text { Warner, } \\
\text { Inc. }\end{array}$ & $\begin{array}{l}\text { Time Warner, Inc. ("TW"), a leading provider of cable } \\
\text { program networks and cable multi-video program distributor } \\
\text { ("MVPD"), proposed to acquire Turner Broadcasting System, } \\
\text { Inc. ("Turner"), which owned several popular cable networks. } \\
\text { The FTC alleged that TW would refuse to carry competitors } \\
\text { of Turner's CNN Network, such as Fox News or MSNBC, and } \\
\text { would raise the price of TW and Turner cable programming to } \\
\text { rival MVPDs. }\end{array}$ & $\begin{array}{l}\text { Input } \\
\text { foreclosure; } \\
\text { customer } \\
\text { foreclosure }\end{array}$ & $\begin{array}{l}\text { Consent Decree required TW (1) to } \\
\text { not bundle its own programming with } \\
\text { Turner programming; (2) to offer } \\
\text { Turner programming to rival MVPDs } \\
\text { at its pre-merger price; and (3) to } \\
\text { carry at least one rival network to } \\
\text { CNN on TW's cable systems. }\end{array}$ \\
\hline 1996 & $\begin{array}{l}\text { In re } \\
\text { Lockheed } \\
\text { Martin } \\
\text { Corporiii }\end{array}$ & $\begin{array}{l}\text { Lockheed Martin Corporation, one of the largest defense and } \\
\text { space contractors in the U.S., proposed to acquire Loral } \\
\text { Corporation, another defense and space contractor. The } \\
\text { proposed acquisition affected several markets. } \\
\text { Loral Corporation was the FAA's systems engineering and } \\
\text { technical services ("SETA") contractor, a position in which it } \\
\text { developed procurement specifications for the agency and } \\
\text { assessed bids. Lockheed participated in many of the }\end{array}$ & $\begin{array}{l}\text { Input } \\
\text { foreclosure; } \\
\text { misuse of } \\
\text { competitors' } \\
\text { sensitive } \\
\text { information; } \\
\text { collusive } \\
\text { information } \\
\text { exchange }\end{array}$ & $\begin{array}{l}\text { Consent Decree required Lockheed } \\
\text { Martin (1) to divest Loral's SETA } \\
\text { contract; (2) to firewall competitively } \\
\text { sensitive information about tactical } \\
\text { fighter manufacturers using Loral } \\
\text { components; (3) to firewall } \\
\text { competitively sensitive information } \\
\text { about unmanned aerial vehicle } \\
\text { manufacturers using Loral integrated }\end{array}$ \\
\hline
\end{tabular}




\begin{tabular}{|c|c|c|c|c|}
\hline \multicolumn{5}{|c|}{ Appendix: Vertical Merger Challenges (1994-2013) } \\
\hline Year & Case & Description & $\begin{array}{c}\text { Vertical Theory } \\
\text { of Harm }\end{array}$ & Remedy \\
\hline & & $\begin{array}{l}\text { procurement auctions for which Loral was the SETA } \\
\text { contractor. The FTC alleged that the acquisition would give } \\
\text { Lockheed access to competitively sensitive information about } \\
\text { competing bidders, as well as allow Lockheed to tailor } \\
\text { procurement specifications or skew bid evaluations to raise } \\
\text { its rivals' costs. } \\
\text { Loral was a supplier of critical components for tactical fighter } \\
\text { aircraft. Lockheed was a manufacturer of tactical fighter } \\
\text { aircraft. The FTC alleged that the acquisition would give } \\
\text { Lockheed access to competitively sensitive information about } \\
\text { its competitors who used Loral's components. } \\
\text { Loral was a supplier of integrated communications systems } \\
\text { for unmanned aerial vehicles. Lockheed was a manufacturer } \\
\text { of unmanned aerial vehicles. The FTC alleged that the } \\
\text { acquisition would give Lockheed access to competitively } \\
\text { sensitive information about its competitors who used Loral's } \\
\text { integrated communications' systems. } \\
\text { As part of the acquisition, Loral's space and } \\
\text { telecommunications business would be transferred to a new } \\
\text { entity (Loral Space) in which Lockheed Martin would obtain a } \\
20 \% \text { convertible preferred equity interest, and under which } \\
\text { Lockheed Martin would provide technical services including } \\
\text { R\&D to Loral Space. The FTC also alleged a horizontal loss } \\
\text { of competition between Lockheed Martin and Loral Space in } \\
\text { commercial low-Earth orbit and geosynchronous orbit } \\
\text { satellites, both from enhanced coordination and unilateral } \\
\text { effects from the partial ownership interest. }\end{array}$ & & $\begin{array}{l}\text { communications systems; (4) to limit } \\
\text { its ownership interest in Loral Space } \\
\text { to 20\%; (5) to not provide any } \\
\text { personnel, information, or facilities to } \\
\text { Loral Space under the technical } \\
\text { services agreement; and (6) to not } \\
\text { share board members or officers with } \\
\text { Loral Space and not compensate any } \\
\text { Lockheed Martin officer or board } \\
\text { member based on the profits of Loral } \\
\text { Space. }\end{array}$ \\
\hline
\end{tabular}




\begin{tabular}{|c|c|c|c|c|}
\hline \multicolumn{5}{|c|}{ Appendix: Vertical Merger Challenges (1994-2013) } \\
\hline Year & Case & Description & $\begin{array}{c}\text { Vertical Theory } \\
\text { of Harm }\end{array}$ & Remedy \\
\hline & $\begin{array}{l}\text { United States } \\
\text { v. The } \\
\text { Thomson } \\
\text { Corp. }^{\text {xxiv }}\end{array}$ & $\begin{array}{l}\text { Thomson Corp., the world's largest publisher of information } \\
\text { for professional markets, proposed to acquire West } \\
\text { Publishing Co., the largest publisher of legal research } \\
\text { materials in the U.S. Thomson licensed primary and } \\
\text { secondary law materials as well as additional services (such } \\
\text { as an electronic citator) to West's primary competitor in } \\
\text { comprehensive online legal research services, Lexis-Nexis. } \\
\text { The DOJ alleged that the acquisition would increase } \\
\text { Thomson's incentive and ability to increase the prices of, } \\
\text { reduce the quality of, or refuse access to Thomson materials } \\
\text { it provides to Lexis-Nexis. The DOJ also alleged horizontal } \\
\text { theories of harm in certain enhanced primary law products } \\
\text { and secondary law materials. }\end{array}$ & Input foreclosure & $\begin{array}{l}\text { Final Judgment required Thomson to } \\
\text { divest the electronic citator it provided } \\
\text { to Lexis and to extend terms of } \\
\text { existing database licenses to Lexis } \\
\text { and to divest assets to remedy the } \\
\text { horizontal overlaps. }\end{array}$ \\
\hline & $\begin{array}{l}\text { In re Boeing } \\
\text { Company }\end{array}$ & $\begin{array}{l}\text { Boeing Company, a manufacturer of high-altitude endurance } \\
\text { unmanned aerial vehicles, proposed to acquire the } \\
\text { Aerospace and Defense Business of Rockwell International } \\
\text { Corporation, which provided wing components to a rival } \\
\text { manufacturer of high-altitude endurance unmanned aerial } \\
\text { vehicles. The FTC alleged that the acquisition would allow } \\
\text { Boeing (1) to deny access to or degrade the quality of the } \\
\text { wings provided to the rival manufacturer of high-altitude } \\
\text { endurance unmanned aerial vehicles; and (2) to access } \\
\text { competitively sensitive information about the rival } \\
\text { manufacturer of high-altitude endurance unmanned aerial } \\
\text { vehicles. }\end{array}$ & $\begin{array}{l}\text { Input } \\
\text { foreclosure; } \\
\text { misuse of } \\
\text { competitors' } \\
\text { sensitive } \\
\text { information }\end{array}$ & $\begin{array}{l}\text { Consent Decree required Boeing (1) } \\
\text { to offer the rival manufacturer of high- } \\
\text { altitude endurance unmanned aerial } \\
\text { vehicles the ability to change to a } \\
\text { different supplier of wing components } \\
\text { and deliver the assets necessary to } \\
\text { do so; and (2) to firewall the } \\
\text { competitively sensitive information of } \\
\text { the rival manufacturer of high-altitude } \\
\text { endurance unmanned aerial vehicles } \\
\text { obtained through supply of wing } \\
\text { components. }\end{array}$ \\
\hline
\end{tabular}




\begin{tabular}{|c|c|c|c|c|}
\hline \multicolumn{5}{|c|}{ Appendix: Vertical Merger Challenges (1994-2013) } \\
\hline Year & Case & Description & $\begin{array}{c}\text { Vertical Theory } \\
\text { of Harm }\end{array}$ & Remedy \\
\hline & $\begin{array}{l}\text { In re } \\
\text { Raytheon } \\
\text { Company }\end{array}$ & $\begin{array}{l}\text { Raytheon Company, a prime contractor bidding for the U.S. } \\
\text { Navy's Submarine High Data Rate Satellite Communications } \\
\text { Terminal, proposed to acquire Chrysler Technologies } \\
\text { Holding, Inc. ("CTH"), a provider of antenna and terminal } \\
\text { controls that were an input into Submarine High Data Rate } \\
\text { Satellite Communications Terminals. Before the merger, } \\
\text { CTH had joined the bidding team for GTE Corporation, a } \\
\text { prime contractor competing with Raytheon. The FTC alleged } \\
\text { that the acquisition would allow Raytheon and GTE to use } \\
\text { CTH as a vehicle to exchange competitively sensitive } \\
\text { information. }\end{array}$ & $\begin{array}{l}\text { Collusive } \\
\text { information } \\
\text { exchange }\end{array}$ & $\begin{array}{l}\text { Consent Decree required Raytheon to } \\
\text { firewall Raytheon's and GTE's } \\
\text { competitively sensitive information } \\
\text { from being exchanged through CTH. }\end{array}$ \\
\hline & $\begin{array}{l}\text { In re Hughes } \\
\text { Danbury } \\
\text { Optical } \\
\text { Systems, } \\
\text { Inc.xxxvii }\end{array}$ & $\begin{array}{l}\text { Hughes Danbury Optical Systems ("HDOS"), a producer of } \\
\text { adaptive optics systems, proposed to acquire Itek Optical } \\
\text { Systems Division of Litton Industries, Inc., a producer of } \\
\text { deformable mirrors. There were two teams developing the } \\
\text { adaptive optics system, which required deformable mirrors, } \\
\text { for the U.S. Air Force's Airborne Laser ("ABL") program; } \\
\text { HDOS was part of the "Rockwell team" while Itek was part of } \\
\text { the "Boeing team." Xinetics Inc., another producer of } \\
\text { deformable mirrors, had an exclusive contract with HDOS. } \\
\text { The FTC alleged that HDOS could (1) foreclose the Boeing } \\
\text { team from access to Itek or Xinetics deformable mirrors; and } \\
\text { (2) gain access to competitively sensitive information of the } \\
\text { Boeing team through Itek. }\end{array}$ & $\begin{array}{l}\text { Input } \\
\text { foreclosure; } \\
\text { misuse of } \\
\text { competitors' } \\
\text { sensitive } \\
\text { information }\end{array}$ & $\begin{array}{l}\text { Consent Decree required HDOS (1) to } \\
\text { not enforce the exclusivity provisions } \\
\text { with Xinetics Inc. for the ABL program; } \\
\text { and (2) to firewall competitively } \\
\text { sensitive information Itek received as } \\
\text { a member of the Boeing team. }\end{array}$ \\
\hline
\end{tabular}




\begin{tabular}{|c|c|c|c|c|}
\hline \multicolumn{5}{|c|}{ Appendix: Vertical Merger Challenges (1994-2013) } \\
\hline Year & Case & Description & $\begin{array}{c}\text { Vertical Theory } \\
\text { of Harm }\end{array}$ & Remedy \\
\hline & $\begin{array}{l}\text { United States } \\
\text { v. Sprint } \\
\text { Corp. }^{\text {xxxviii }}\end{array}$ & $\begin{array}{l}\text { Sprint Corp., France Telecom ("FT"), and Deutsche Telekom } \\
\text { ("DT") proposed to form a joint venture for international } \\
\text { telecommunication services. Additionally, FT and DT agreed } \\
\text { to acquire } 20 \% \text { of voting equity in Sprint. The DOJ alleged } \\
\text { that the JV could: (1) restrict competitors from accessing } \\
\text { French and German public switched networks, infrastructure, } \\
\text { and public data networks controlled by FT and DT; (2) deny } \\
\text { operating agreements for a correspondent system in France } \\
\text { and Germany to competitors of the JV, which were necessary } \\
\text { for telecommunications traffic; and (3) obtain confidential } \\
\text { information from other U.S. carriers through the Sprint } \\
\text { ownership and JV participation. }\end{array}$ & $\begin{array}{l}\text { Input } \\
\text { foreclosure; } \\
\text { misuse of } \\
\text { competitors' } \\
\text { sensitive } \\
\text { information; } \\
\text { collusive } \\
\text { information } \\
\text { exchange }\end{array}$ & $\begin{array}{l}\text { Final Judgment required (1) FT and } \\
\text { DT to make services available to } \\
\text { competitors of the JV on a non- } \\
\text { discriminatory basis; (2) Sprint to } \\
\text { forego providing correspondent } \\
\text { telecommunication services with } \\
\text { France or Germany unless another } \\
\text { provider has an operating agreement; } \\
\text { (3) Sprint to disclose certain } \\
\text { information about its agreements with } \\
\text { DT and FT; and (4) FT and DT to } \\
\text { firewall Sprint and the JV from } \\
\text { competitively sensitive information of } \\
\text { Sprint's rivals. The Final Judgment } \\
\text { also imposed certain additional } \\
\text { restrictions until facilities-based } \\
\text { competition with FT and DT were } \\
\text { legalized in their home countries. }\end{array}$ \\
\hline & $\begin{array}{l}\text { In re Silicon } \\
\text { Graphics, } \\
\text { Inc. }\end{array}$ & $\begin{array}{l}\text { Silicon Graphics, Inc. ("SGl”), a supplier of entertainment } \\
\text { graphics workstations, proposed to acquire Alias Research } \\
\text { Inc ("Alias"). and Wavefront Technology Inc. ("Wavefront”), } \\
\text { two developers of entertainment graphics software. The FTC } \\
\text { alleged that the new entity could foreclose rival workstation } \\
\text { producers from accessing critical entertainment graphics } \\
\text { software and could foreclose competing entertainment } \\
\text { graphics companies from developing software compatible } \\
\text { with SGl's workstations. Additionally, Silicon could access } \\
\text { competitively sensitive information related to other } \\
\text { workstation producers through their use of Alias or Wavefront } \\
\text { entertainment graphics software. }\end{array}$ & $\begin{array}{l}\text { Complementary } \\
\text { products } \\
\text { foreclosure; } \\
\text { misuse of } \\
\text { competitors' } \\
\text { sensitive } \\
\text { information }\end{array}$ & $\begin{array}{l}\text { Consent Decree required SGI (1) to } \\
\text { enter an agreement with a rival } \\
\text { workstation provider to port Alias's } \\
\text { and Wavefront's entertainment } \\
\text { graphics software to the rivals' } \\
\text { systems; (2) to maintain an open } \\
\text { architecture for SGI systems and } \\
\text { publish SGI systems' application } \\
\text { programming interfaces; and (3) to } \\
\text { maintain a software development } \\
\text { program for rivals of Alias and } \\
\text { Wavefront with similar terms to those } \\
\text { used for other development programs. }\end{array}$ \\
\hline
\end{tabular}




\begin{tabular}{|c|c|c|c|c|}
\hline \multicolumn{5}{|c|}{ Appendix: Vertical Merger Challenges (1994-2013) } \\
\hline Year & Case & Description & $\begin{array}{c}\text { Vertical Theory } \\
\text { of Harm }\end{array}$ & Remedy \\
\hline & $\begin{array}{l}\text { In re Alliant } \\
\text { Techsystems } \\
\text { Inc. }{ }^{x l}\end{array}$ & $\begin{array}{l}\text { Alliant Techsystems Inc. ("Alliant"), a manufacturer of } \\
\text { ammunition and munitions, proposed to acquire Hercules } \\
\text { Incorporated's aerospace division, a supplier of propellant } \\
\text { used in large caliber ammunition. The FTC alleged that } \\
\text { Alliant would gain access to competitors' confidential } \\
\text { information regarding munitions through its role as a supplier } \\
\text { of propellant. }\end{array}$ & $\begin{array}{l}\text { Misuse of } \\
\text { competitors' } \\
\text { sensitive } \\
\text { information; } \\
\text { collusive } \\
\text { information } \\
\text { exchange }\end{array}$ & $\begin{array}{l}\text { Consent Decree required Alliant to } \\
\text { firewall competitively sensitive } \\
\text { information gained through Alliant's } \\
\text { capacity as a propellant provider. }\end{array}$ \\
\hline & $\begin{array}{l}\text { In re Eli Lilly \& } \\
\text { Co., Inc. }\end{array}$ & $\begin{array}{l}\text { Eli Lilly and Co., a manufacturer of pharmaceuticals, } \\
\text { proposed to acquire McKesson, Inc., which through its PCS } \\
\text { Health Systems, Inc. ("PCS") subsidiary provided pharmacy } \\
\text { benefit management ("PBM") services. As part of its PBM } \\
\text { services, PCS maintained a drug formulary, which included } \\
\text { several of Eli's Lilly's drugs. The FTC alleged that (1) } \\
\text { competing manufacturer's drugs would likely be foreclosed } \\
\text { from the PCS formulary; (2) Eli Lilly would have access to } \\
\text { competitors' proprietary information through the PBM } \\
\text { services; and (3) PCS would be eliminated as an } \\
\text { independent negotiator of pharmaceutical prices. }\end{array}$ & $\begin{array}{l}\text { Customer } \\
\text { foreclosure; } \\
\text { misuse of } \\
\text { competitors' } \\
\text { sensitive } \\
\text { information; } \\
\text { collusive } \\
\text { information } \\
\text { exchange; } \\
\text { elimination of } \\
\text { disruptive buyer. }\end{array}$ & $\begin{array}{l}\text { Consent Decree required Eli Lilly (1) } \\
\text { to maintain an open formulary } \\
\text { implemented by an independent } \\
\text { committee and to reflect all discounts } \\
\text { and rebates offered by other drug } \\
\text { manufacturers on the open formulary; } \\
\text { (2) to firewall Lilly's competitively } \\
\text { sensitive information from being } \\
\text { released to Lilly competitors through } \\
\text { PCS; (3) to firewall PCS's confidential } \\
\text { information from being released to } \\
\text { PCS competitors through Lilly. }\end{array}$ \\
\hline & $\begin{array}{l}\text { In re } \\
\text { Lockheed } \\
\text { Corp. and } \\
\text { Martin } \\
\text { Marietta } \\
\text { Corp. }^{\text {xlii }}\end{array}$ & $\begin{array}{l}\text { Lockheed Corp., a manufacturer of military aircraft, and } \\
\text { Martin Marietta Corp., a supplier of an infrared navigation and } \\
\text { targeting system ("LANTIRN") for military aircraft, proposed } \\
\text { to merge. The FTC alleged that (1) the company could } \\
\text { modify Martin Marietta's LANTIRN systems to raise the costs } \\
\text { of competing military aircraft; and (2) Lockheed's military } \\
\text { aircraft division could access rival military aircraft } \\
\text { manufacturers' sensitive information shared with Martin } \\
\text { Marietta to use its LANTIRN system. The FTC also alleged } \\
\text { horizontal losses of competition in the development of } \\
\text { expendable launch vehicles, in satellites for use in space- } \\
\text { based early warning systems, and in certain sensors. }\end{array}$ & $\begin{array}{l}\text { Input } \\
\text { foreclosure; } \\
\text { misuse of } \\
\text { competitors' } \\
\text { sensitive } \\
\text { information }\end{array}$ & $\begin{array}{l}\text { Consent Decree required the merged } \\
\text { firm (1) to not modify the LANTIRN } \\
\text { system in a way that discriminated } \\
\text { against rival aircraft manufacturers } \\
\text { unless necessary; (2) to firewall } \\
\text { competitively sensitive information } \\
\text { from military aircraft competitors } \\
\text { obtained by Martin Marietta as part of } \\
\text { their use of the LANTIRN system; and } \\
\text { (3) to refrain from enforcing certain } \\
\text { teaming agreements to remove the } \\
\text { horizontal overlaps. }\end{array}$ \\
\hline
\end{tabular}




\begin{tabular}{|c|c|c|c|c|}
\hline \multicolumn{5}{|c|}{ Appendix: Vertical Merger Challenges (1994-2013) } \\
\hline Year & Case & Description & $\begin{array}{c}\text { Vertical Theory } \\
\text { of Harm }\end{array}$ & Remedy \\
\hline \multirow[t]{3}{*}{1994} & $\begin{array}{l}\text { In re Martin } \\
\text { Marietta } \\
\text { Corp. }^{\text {xliii }}\end{array}$ & $\begin{array}{l}\text { Martin Marietta Corp., a manufacturer of satellites, proposed } \\
\text { to acquire General Dynamics Corp.'s Space Systems } \\
\text { Division, which produced expendable launch vehicles. The } \\
\text { FTC alleged that Martin Marietta could access confidential } \\
\text { information of competing satellite suppliers through its role as } \\
\text { a provider of expendable launch vehicles. }\end{array}$ & $\begin{array}{l}\text { Misuse of } \\
\text { competitors' } \\
\text { sensitive } \\
\text { information }\end{array}$ & $\begin{array}{l}\text { Consent Decree required Martin } \\
\text { Marietta to firewall competitively } \\
\text { sensitive information of rival satellite } \\
\text { producers obtained in its role as a } \\
\text { provider of expendable launch } \\
\text { vehicles. }\end{array}$ \\
\hline & $\begin{array}{l}\text { United States } \\
v, A T \& T^{x l i v}\end{array}$ & $\begin{array}{l}\text { AT\&T Corp., the largest U.S. long distance telephone } \\
\text { company and a provider of cellular infrastructure equipment, } \\
\text { proposed to acquire McCaw Cellular Communications, the } \\
\text { largest cellular carrier. The DOJ alleged that (1) AT\&T would } \\
\text { limit access to or raise the price of its cellular infrastructure } \\
\text { equipment to networks competing with McCaw's; (2) McCaw } \\
\text { could gain access to its competitors' competitively sensitive } \\
\text { information through their use of AT\&T equipment; (3) AT\&T } \\
\text { could gain access to its competitors' competitively sensitive } \\
\text { information through McCaw's use of their equipment; and (4) } \\
\text { McCaw could steer its customers to using AT\&T's } \\
\text { interexchange services, eliminating competition between } \\
\text { AT\&T and rival interexchange service providers. }\end{array}$ & $\begin{array}{l}\text { Input } \\
\text { foreclosure; } \\
\text { customer } \\
\text { foreclosure; } \\
\text { misuse of } \\
\text { competitors' } \\
\text { sensitive } \\
\text { information }\end{array}$ & $\begin{array}{l}\text { Final Judgment required AT\&T (1) to } \\
\text { provide equal access to } \\
\text { interexchange competitors of AT\&T; } \\
\text { (2) to firewall competitively sensitive } \\
\text { information McCaw obtained from } \\
\text { competing cellular infrastructure } \\
\text { equipment providers; (3) to firewall } \\
\text { competitively sensitive information } \\
\text { AT\&T obtain from competing cellular } \\
\text { carriers; and (4) to continue to deal } \\
\text { with cellular infrastructure equipment } \\
\text { customers on current terms and on } \\
\text { terms equal to those provided to } \\
\text { McCaw. } \\
\end{array}$ \\
\hline & $\begin{array}{l}\text { United States } \\
\text { v. MCl } \\
\text { Commc'ns } \\
\text { Corp }^{x l v} \text {. }\end{array}$ & $\begin{array}{l}\text { British Telecommunications plc. ("BT") proposed to acquire } \\
20 \% \text { interest in MCI Communications Corp. and to form a } \\
\text { joint venture for global telecommunication services. Global } \\
\text { telecommunications services were provided on a } \\
\text { "correspondent" basis, in which providers completed each } \\
\text { other's traffic. The DOJ alleged that: (1) BT could use pricing } \\
\text { or contract terms to favor MCl for international } \\
\text { correspondence services; (2) MCl could gain access to } \\
\text { competitors' competitively sensitive information through their } \\
\text { relationships with BT; and (3) BT could send all or most of its } \\
\text { international switch traffic to MCl. }\end{array}$ & $\begin{array}{l}\text { Input } \\
\text { foreclosure; } \\
\text { customer } \\
\text { foreclosure; } \\
\text { misuse of } \\
\text { competitors' } \\
\text { sensitive } \\
\text { information; } \\
\text { collusive } \\
\text { information } \\
\text { exchange }\end{array}$ & $\begin{array}{l}\text { Final Judgment required BT (1) to } \\
\text { follow transparency and disclosure } \\
\text { requirements for telecommunication } \\
\text { services between BT and MCl; and } \\
\text { (2) to firewall competitively sensitive } \\
\text { information from MCl's competitors } \\
\text { obtained through BT's correspondent } \\
\text { services. }\end{array}$ \\
\hline
\end{tabular}




\begin{tabular}{|c|c|c|c|c|}
\hline \multicolumn{5}{|c|}{ Appendix: Vertical Merger Challenges (1994-2013) } \\
\hline Year & Case & Description & $\begin{array}{c}\text { Vertical Theory } \\
\text { of Harm }\end{array}$ & Remedy \\
\hline & $\begin{array}{l}\text { United States } \\
\text { v. Tele- } \\
\text { Commc'ns } \\
\text { Inc. }^{x l v i}\end{array}$ & $\begin{array}{l}\text { Tele-Communications, Inc. ("TCl") and Liberty Media Corp. } \\
\text { ("Liberty"), both large cable multichannel subscription } \\
\text { television distributors ("MSTDs") that had interests in video } \\
\text { programming networks, proposed to merge. Before the } \\
\text { merger, the firms had substantial cross-ownership and } \\
\text { cooperated closely. The DOJ alleged that, although their } \\
\text { cross-ownership and differing service areas had already } \\
\text { eliminated horizontal competition, the merger would (1) give } \\
\text { each company the incentive to deny or make more expensive } \\
\text { to rival video programming networks carriage on their cable } \\
\text { systems; and (2) give each company the incentive to deny or } \\
\text { make more expensive to rival MSTDs the programming from } \\
\text { their video programming networks. }\end{array}$ & $\begin{array}{l}\text { Input } \\
\text { foreclosure; } \\
\text { customer } \\
\text { foreclosure }\end{array}$ & $\begin{array}{l}\text { Final Judgment required the merged } \\
\text { firm (1) to not discriminate in providing } \\
\text { carriage on its cable systems to rival } \\
\text { video programming networks, where } \\
\text { the effect would be to unreasonably } \\
\text { restrain competition; and (2) to not } \\
\text { discriminate in providing its video } \\
\text { programming services to rival MSTDs, } \\
\text { where the effect would be to } \\
\text { unreasonably restrain competition. }\end{array}$ \\
\hline
\end{tabular}

' In re Nielsen Holdings N.V., No. 131-0058 (F.T.C. Sept. 20, 2013), available at http://www.ftc.gov/enforcement/cases-proceedings/1310058/nielsen-holdings-nv-arbitron-inc-matter.

ii In re General Electric Company, No. 131-0069 (F.T.C. July 19, 2013), available at http://www.ftc.gov/enforcement/cases-proceedings/1310069/general-electric-company-matter.

iii United States v. Comcast Corp., No. 1:11-cv-00106, (D.D.C. Jan 18, 2011), available at http://www.justice.gov/atr/cases/comcast.html.

iv United States v. GrafTech International Ltd., No. 1:10-cv-02039 (D.D.C. November 29, 2010), available at

http://www.justice.gov/atr/cases/graftech.html.

$\checkmark$ United States v. Google Inc., No. 1:11-cv-00688 (D.D.C. Apr. 8, 2011), available at http://www.justice.gov/atr/cases/google.html.

vi In re Coca-Cola Company, No. 101-0107 (F.T.C. Sept. 27, 2010), available at http://www.ftc.gov/enforcement/cases-proceedings/101-

0107/coca-cola-company-matter.

vii In re PepsiCo, Inc., No. $091-0133$ (F.T.C. Feb, 26, 2010), available at http://www.ftc.gov/enforcement/cases-proceedings/091-0133/pepsico-incmatter.

viii United States v. Ticketmaster Entertainment, Inc., No. 1:10-cv-00139 (D.D.C. Jan. 25, 2010), available at

http://www.justice.gov/atr/cases/ticket.htm.

ix In re Fresenius Medical Care AG \& Co. KGaA, No. 081-0146 (F.T.C. Sept. 15, 2008), available at http://www.ftc.gov/enforcement/casesproceedings/081-0146/fresenius-medical-care-ag-co-kgaa-et-al-matter. 
× United States v. Monsanto Co., No. 1:07-cv-00992 (D.D.C. May 31, 2007), available at http://www.justice.gov/atr/cases/monsanto.htm.

${ }^{x i}$ In re Lockheed Martin Corp., FTC Docket No. 051-0165 (Oct 3. 2006), available at http://www.ftc.gov/enforcement/cases-

proceedings/0510165/lockheed-martin-corporation-boeing-company-united-launch.

xii United States v. Northrop Grumman Corp., No. 1:02CV02432 (D.D.C. Dec. 23, 2002), available at

http://www.justice.gov/atr/cases/northrop.htm.

xiii In re America Online, Inc., No. C-3989 (F.T.C. Dec. 14, 2000), available at http://www.ftc.gov/enforcement/cases-

proceedings/0010105/america-online-inc-time-warner-inc.

xiv Cytyc and Digene abandoned the transaction in response to FTC scrutiny. Press Release, Fed. Trade Comm'n, FTC Seeks to Block Cytyc Corp's Acquisition of Digene Corp. (June 24, 2002), http://www.ftc.gov/news-events/press-releases/2002/06/ftc-seeks-block-cytyc-corpsacquisition-digene-corp.

xv United States v. Premdor, Inc., No. 1:01-cv-01696 (D.D.C. Aug. 3, 2001), available at http://www.justice.gov/atr/cases/indx327.htm.

${ }^{x v i}$ In re Entergy Corporation and Entergy-Koch, LP, No. C-3998 (F.T.C. Feb. 23, 2001), available at http://www.ftc.gov/enforcement/casesproceedings/0010172/entergy-corporation-entergy-koch-lp.

In re Ceridian Corp., FTC Docket No. 9810030 (Sept. 29, 1999), available at http://www.ftc.gov/enforcement/cases-

proceedings/9810030/ceridian-corporation-matter.

viii In re Boeing Company, No. C-3992 (F.T.C. Sept. 27, 2000), available at http://www.ftc.gov/enforcement/cases-proceedings/0010092/boeingcompany.

xix United States v. Enova Corp., 107 F. Supp. 2d 10 (D.D.C. Jun. 8, 1998), available at http://www.justice.gov/atr/cases/indx47.htm.

$x x$ The parties abandoned the transaction in response to FTC scrutiny. See Sheila F. Anthony, "Vertical Issues: The Federal View," (Mar. 9,

2000) (discussing Barnes \& Noble/Ingram proposed merger), http://www.ftc.gov/public-statements/2000/03/vertical-issues-federal-view. See also

Press Release, Fed. Trade Comm'n, FTC Testifies Before House Judiciary Committee on Commission's Antitrust Enforcement Activities (Apr. 12 2000), http://www.ftc.gov/news-events/press-releases/2000/04/ftc-testifies-house-judiciary-committee-commissions-antitrust.

In re Provident Companies, Inc. and UNUM Corporation, No. C-3894 (Sept. 20, 1999), available at http://www.ftc.gov/enforcement/cases-

proceedings/9910101/provident-companies-inc-unum-corporation.

xii In re Merck \& Co., FTC Docket No. 9510097 (Aug 27, 1998), available at http://www.ftc.gov/enforcement/cases-proceedings/9510097/merckco-inc-merck-medco-managed-care-llc

xxiii In re CMS Energy Corporation, No. C-3877 (F.T.C. Mar. 19, 1999), available at http://www.ftc.gov/enforcement/cases-

proceedings/9910046/cms-energy-corporation.

xxiv United States v. SBC Comm'ns Inc., No. 99-0715 (D.D.C. Mar. 23, 1999), http://www.justice.gov/atr/cases/indx123.htm.

xxv In re Dominion Resources, Inc. and Consolidated Natural Gas Company, No. C-3901 (F.T.C. Nov. 5, 1999), available at

http://www.ftc.gov/enforcement/cases-proceedings/9910244/dominion-resources-inc-consolidated-natural-gas-company.

xxvi The parties abandoned the transaction after the DOJ filed a complaint. See Antitrust Division FY 2001 Budget Request, Hearing Before the Subcomm. on Antitrust, Business Rights and Competition of the S. Comm. on the Judiciary (Mar. 22, 200) (statement of Joel I. Klein, Asst.

Attorney Gen.), available at http://www.justice.gov/atr/public/testimony/4381.htm. See also United States v. Lockheed Martin Corp., No. 98-CV 00731 (D.D.C. Mar. 23, 1998), available at http://www.justice.gov/atr/cases/indx27.htm.

xxvii In re PacifiCorp, No. 971001 (F.T.C. Feb. 18, 1998), available at http://www.ftc.gov/enforcement/cases-proceedings/9710091/pacificorp-

energy-group-plc-peabody-holding-company-inc. The transaction was abandoned for unrelated reasons. Press Release, Fed. Trade Comm'n, 
FTC Withdraws Proposed Consent Agreement, Closes Pacificorp Investigation (Jul. 2, 1998), http://www.ftc.gov/news-events/pressreleases/1998/07/ftc-withdraws-proposed-consent-agreement-closes-pacificorp.

xxviii The parties abandoned the transaction after the DOJ filed suit, at an early stage in the litigation. See U.S. Dep't of Just. \& Fed. Trade Comm'n, Annual Report to Congress Pursuant to Subsection (j) of Section 7A of the Clayton Act Hart-Scott-Rodino Antitrust Improvements Act of 1976 (Feb. 1999), http://www.ftc.gov/reports/21st-report-fy-1998. See also United States v. Primestar, Inc., No. 1:98CV01193 (D.D.C. Jun. 29, 1998), available at http://www.justice.gov/atr/cases/indx41.htm.

xxix In re TRW, Inc., No. C-3790 (F.T.C. Dec. 24, 1997), available at http://www.ftc.gov/enforcement/cases-proceedings/9810081/trw-inc.

xxx In re Shell Oil Company and Texaco Inc., No. C-3803 (F.T.C. Dec. 19, 1997), available at http://www.ftc.gov/enforcement/casesproceedings/971-0026/shell-oil-company-texaco-inc.

xxxi In re Cadence Design Sys. Inc., No. C-3761 (F.T.C. May 8, 1997), available at http://www.ftc.gov/enforcement/cases-proceedings/971-0033-c3761/cadence-design-systems-inc.

xxxii Analysis of Proposed Agreement Containing Consent Order to Aid Public Comment, In re Time Warner, Inc. 123 F.T.C. 171 (1997), available at http://www.ftc.gov/system/files/documents/commission_decision_volumes/volume-123/volume123a.pdf\#page=179.

xxxiii In re Lockheed Martin Corporation, No. C-3685 (F.T.C. Sept. 20, 1996), available at http://www.ftc.gov/enforcement/cases-

proceedings/9610026/lockheed-martin-corporation. See also Press Release, Fed. Trade Comm'n, Lockheed Martin To Settle Charges in Loral Acquisition (Apr. 18, 1996), http://www.ftc.gov/news-events/press-releases/1996/04/lockheed-martin-settle-charges-loral-acquisition.

xxxiv United States v. Thomson Corp., No. 96-1415 (D.D.C. June 25, 1996), available at http://www.justice.gov/atr/cases/thetho0.htm.

xxxv In re Boeing Company, No. C-3723 (F.T.C. Dec. 5, 1996), http://www.ftc.gov/enforcement/cases-proceedings/9710006/boeing-companymatter.

xxxvi In re Raytheon Company, No. C-3681 (F.T.C. Sept. 10, 1996), available at http://www.ftc.gov/enforcement/cases-

proceedings/9610057/raytheon-company.

xxvii In re Hughes Danbury Optical Sys., 121 F.T.C. 495 (1996), available at

http://www.ftc.gov/sites/default/files/documents/commission_decision_volumes/volume-121/ftc_volume_decision_121_january_june_1996pages_477-560.pdf\#page=19.

xxxviii United States v. Sprint Corp., No. 95-CV-1304 (D.D.C. July 13, 1995), available at http://www.justice.gov/atr/cases/sprint1.htm.

xxxix In re Silicon Graphics, Inc., 120 F.T.C. 928 (1995), available at

http://www.ftc.gov/sites/default/files/documents/commission_decision_volumes/volume-120/ftc_volume_decision_120_july_-

december_1995pages_893_-_1002.pdf\#page=36.

ता In re Alliant Techsystems Inc., 119 F.T.C. 440 (1995) available at

http://www.ftc.gov/sites/default/files/documents/commission_decision_volumes/volume-119/ftc_volume_decision_119 january_-

june_1995pages_413-517.pdf\#page=28.

तl In re Eli Lilly \& Co., 120 F.T.C. 243 (1995), available at http://www.ftc.gov/sites/default/files/documents/commission_decision_volumes/volume120/ftc_volume_decision_120_july_-_december_1995pages_206_-_311.pdf\#page=38.

xlii In re Lockheed Corp., 119 F.T.C. 618 (1995), available at

http://www.ftc.gov/sites/default/files/documents/commission_decision_volumes/volume-119/ftc_volume_decision_119_january_june_1995pages_618-723.pdf. 
xliii In re Martin Marietta Corp., 117 F.T.C. 1039 (1994), available at

http://www.ftc.gov/sites/default/files/documents/commission_decision_volumes/volume-117/ftc_volume_decision_117_january_june_1994pages_971_-_1074.pdf\#page=69.

Competitive Impact Statement, United States v. AT\&T Corp., 59 Fed. Red. 44,158 (D.D.C. 1994), available at http://www.gpo.gov/fdsys/pkg/FR-1994-08-26/html/94-20948.htm.

United States v. MCl Commc'ns, 1994-2 Trade Cas. (CCH) ๆ 70,730 (D.D.C. June 15, 1994), available at http://www.justice.gov/atr/cases/mci0000.htm.

xvi United States v. Tele-Commc'ns Inc., 1196-2 Trad Cas. (CCH) I 71,496 (D.D.C. Apr. 28, 1994), available at http://www.justice.gov/atr/cases/teleco0.htm. 